\title{
Pro- and Anti-Mitogenic Actions of Pituitary Adenylate Cyclase-Activating Polypeptide in Developing Cerebral Cortex: Potential Mediation by Developmental Switch of PAC1 Receptor mRNA Isoforms
}

\author{
Yan Yan, ${ }^{1,3}$ Xiaofeng Zhou, ${ }^{1}$ Zui Pan, ${ }^{2}$ Jianjie Ma, ${ }^{2}$ James A. Waschek, ${ }^{5}$ and Emanuel DiCicco-Bloom ${ }^{1,3,4}$ \\ Departments of ${ }^{1}$ Neuroscience and Cell Biology, ${ }^{2}$ Physiology and Biophysics, and ${ }^{3}$ Joint Graduate Program in Cell and Developmental Biology, University of \\ Medicine and Dentistry of New Jersey-Robert Wood Johnson Medical School, Piscataway, New Jersey 08854, ${ }^{4}$ Department of Pediatrics, University of \\ Medicine and Dentistry of New Jersey-Robert Wood Johnson Medical School, New Brunswick, New Jersey 08901, and ${ }^{5}$ Department of Psychiatry, \\ Intellectual and Developmental Disabilities Research Center, University of California at Los Angeles, Los Angeles, California 90095
}

During corticogenesis, pituitary adenylate cyclase-activating polypeptide (PACAP; ADCYAP1) may contribute to proliferation control by activating PAC1 receptors of neural precursors in the embryonic ventricular zone. PAC1 receptors, specifically the hop and short isoforms, couple differentially to and activate distinct pathways that produce pro- or anti-mitogenic actions. Previously, we found that PACAP was an anti-mitogenic signal from embryonic day 13.5 (E13.5) onward both in culture and in vivo and activated cAMP signaling through the short isoform. However, we now find that mice deficient in PACAP exhibited a decrease in the BrdU labeling index (LI) in E9.5 cortex, suggesting that PACAP normally promotes proliferation at this stage. To further define mechanisms, we established a novel culture model in which the viability of very early cortical precursors (E9.5 mouse and E10.5 rat) could be maintained. At this stage, we found that PACAP evoked intracellular calcium fluxes and increased phospho-PKC levels, as well as stimulated G1 cyclin mRNAs and proteins, S-phase entry, and proliferation without affecting cell survival. Significantly, expression of hop receptor isoform was 24-fold greater than the short isoform at E10.5, a ratio that was reversed at E14.5 when short expression was 15-fold greater and PACAP inhibited mitogenesis. Enhanced hop isoform expression, elicited by in vitro treatment of E10.5 precursors with retinoic acid, correlated with sustained pro-mitogenic action of PACAP beyond the developmental switch. Conversely, depletion of hop receptor using short-hairpin RNA abolished PACAP mitogenic stimulation at E10.5. These observations suggest that PACAP elicits temporally specific effects on cortical proliferation via developmentally regulated expression of specific receptor isoforms.

\section{Introduction}

In developing cerebral cortex, positive and negative regulation of neuronal precursor proliferation and differentiation by extracellular factors influences correct cell types and numbers (Vaccarino et al., 1999; Ménard et al., 2002). The pituitary adenylate cyclaseactivating polypeptide (PACAP) ligand/PAC1 receptor system is expressed widely in multiple regions of the embryonic nervous system. The actions of PACAP signaling are complex: the peptide

\footnotetext{
Received March 4, 2012; revised Dec. 23, 2012; accepted Jan. 8, 2013.

Author contributions: Y.Y. and E.D.-B. designed research; Y.Y., X.Z., and Z.P. performed research; J.M. and J.A.W. contributed unpublished reagents/analytic tools; Y.Y., X.Z., Z.P., and E.D.-B. analyzed data; Y.Y., J.A.W., and E.D.-B. wrote the paper.

This work was supported by National Institutes of Health Grant NS32401 (E.D.-B.), HL069000 and AG028614 (J.A.W.), and HD34475, HD06576, and HD04612 (J.A.W.) and University of Medicine and Dentistry of New Jersey Foundation Grant 62-09 (Z.P.). We thank Karl Herrup for valuable critical review, Richard Mains for inspiring guidance and discussion, and Betty Eipper and Yanping Wang for technical support.

The authors declare no competing financial interests.

Correspondence should be addressed to Emanuel DiCicco-Bloom, Department of Neuroscience and Cell Biology, University of Medicine and Dentistry of New Jersey-Robert Wood Johnson Medical School, 675 Hoes Lane, Room 362, Piscataway, NJ 08854. E-mail: diciccem@umdnj.edu.

DOI:10.1523/JNEUROSCI.1062-12.2013

Copyright $\odot 2013$ the authors $\quad 0270-6474 / 13 / 333865-14 \$ 15.00 / 0$
}

functions in precursor cell cycle progression, differentiation, and survival. Although previous studies support this contention, it is apparent that PACAP is an anti-mitogenic signal in most contexts (Lu and DiCicco-Bloom, 1997; Waschek et al., 1998; Suh et al., 2001; Nicot et al., 2002; Vaudry et al., 2002b). Defining the role of PACAP in brain development may be important because recent studies suggest that PACAP signaling abnormalities may contribute to schizophrenia (Hashimoto et al., 2007), posttraumatic stress disorder (PTSD) (Ressler et al., 2011), and possibly autism (Nijmeijer et al., 2010).

PACAP acts on heptahelical G-protein-coupled receptors (GPCRs): PAC1, VPAC1, and VPAC2 (Harmar et al., 1998). $\mathrm{PACl}$ is the most abundant receptor especially in CNS (Spengler et al., 1993; Basille et al., 2000) and has multiple splice isoforms, which are characterized by the absence (short) or presence of a 28 aa insert (hop) in the third intracellular loop (Spengler et al., 1993). Significantly, the short isoform and the insert-containing, hop isoform couple to different transduction pathways (Spengler et al., 1993; Vaudry et al., 2002a) and exhibit anti- or promitogenic effects, respectively. In embryonic day 13.5 (E13.5) or later cortical precursors, which predominantly express the short 
isoform that increases cAMP levels and activates PKA, PACAP elicits cell cycle exit and promotes differentiation ( $\mathrm{Lu}$ and DiCicco-Bloom, 1997; Lu et al., 1998), a finding replicated in vivo (Suh et al., 2001). In sharp contrast, the hop isoform activates both adenylate cyclase and phospholipase C (PLC) pathways and mediates mitogenic stimulation (Lu et al., 1998; DiCicco-Bloom et al., 2000). Furthermore, ectopic overexpression of hop isoform in E14.5 precursors converted PACAP anti-mitogenic effects into pro-mitogenic activity (Nicot and DiCicco-Bloom, 2001). These results suggest that the natural expression of different PAC1 isoforms is important for regulating precursor mitosis.

The presence of total PAC1 gene transcripts as well as both individual short and hop mRNA isoforms has been reported from primitive streak stage E9 to postnatal periods (Waschek et al., 1998; Basille et al., 2000; Zhou et al., 2000; Vaudry et al., 2009). Moreover, in situ hybridization shows intense and apparently overlapping expression of short and hop receptor mRNAs in E10 telencephalon as well as E13 ventricular zone (VZ) and cortical plate (Zhou et al., 2000). However, the relative expression levels of short and hop during early corticogenesis are undefined. Moreover, although evidence links PAC1 isoforms to anti-mitogenic effects from E13.5 onward, functions of the PACAP system in early neurogenesis, when precursors proliferate to expand precursor pools, remain unresolved. Given that hop is pro-mitogenic, PACAP is a potential mitogen during this critical period. Here, assessing rat and mouse precursors, we tested the hypothesis that PACAP exhibits distinct mitogenic activities during corticogenesis, depending on $\mathrm{PAC1}$ receptor isoforms. We found that E10.5 precursors predominantly express hop, whereas the short mRNA is upregulated and becomes dominant at E14.5. Blockade of hop expression using short-hairpin RNA (shRNA) abolished PACAP mitogenic effects at E10.5. PACAP evokes calcium fluxes, increases phospho-PKC levels, and stimulates proliferation at E10.5 but not E14.5, suggesting that control of mRNA isoform expression contributes to neurogenetic regulation.

\section{Materials and Methods}

Animals. Time-mated pregnant Sprague Dawley rats were obtained from Hilltop Lab Animals. Breeding pairs of PACAP knock-out (KO) mice on a C57BL/6 background were derived by Waschek as described previously (Colwell et al., 2004). Animals were managed by Robert Wood Johnson Animal Facility, and maintenance, husbandry, transportation, housing, and use were in compliance with Laboratory Animal Welfare Act (PL 89-544; PL-91-579) and National Institutes of Health guidelines (Manual Chapter 4206). Food and water were available ad libitum. The day of the plug was considered E0.5.

BrdU labeling of PACAP wild-type and KO mice. To maximize comparability, wild-type (WT) and KO littermates of either sex from heterozygous PACAP matings were analyzed. BrdU at $100 \mu \mathrm{g} / \mathrm{g}$ was injected into E9.5 pregnant mice $1 \mathrm{~h}$ before they were killed. Embryo brains were immersion fixed in $4 \%$ paraformaldehyde (PFA) for $30 \mathrm{~min}$ at $4^{\circ} \mathrm{C}$, processed for paraffin embedding, and sectioned coronally at $6 \mu \mathrm{m}$. Sections were immunostained for BrdU incorporation and counterstained with propidium iodide (PI) as reported previously (Mairet-Coello et al., 2009). Images of embryos identified by number alone (not genotype) were obtained from a Carl Zeiss LSM 510-META confocal microscope. BrdU-positive nuclei and total nuclei were counted blind on coronal sections in the mid-dorsolateral cortex within a 100 - $\mu \mathrm{m}$-wide sector based on the ventricular surface extending to the VZ/intermediate zone boundary. BrdU LIs were calculated as the BrdU-positive cells over total cells as described previously (Suh et al., 2001). Tissue from each embryo was used to determine genotype using touchdown PACAP PCR and primers described previously (Colwell et al., 2004).

Cell cultures. Embryos of either sex of E10.5-E14.5 Sprague Dawley rats or E9.5-E13.5 C57BL/6 mice were dissected under a dissecting microscope.
E10.5 rat and E9.5 mouse telencephalic vesicles were incubated with trypsin $\left(0.25 \mathrm{mg} / \mathrm{ml}\right.$; Sigma-Aldrich) at $37^{\circ} \mathrm{C}$ for $12 \mathrm{~min}$, followed by trypsin inhibitor $(1 \mathrm{mg} / \mathrm{ml})$ to aid in removing overlying epidermal ectoderm using dissecting forceps. The dorsolateral cortices were isolated and mechanically dissociated using a fire-polished glass pipette. Cells were plated on $2 \mu \mathrm{g} / \mathrm{ml}$ poly-D-lysine-coated 96-well plates (10,000 cells per well), 24-well plates (25,000 cells per well), or $35 \mathrm{~mm}$ dishes (80,000 cells per dish) in defined medium consisting of a 1:1 mixture of DMEM and F-12, as described previously (Lu and DiCicco-Bloom, 1997; Mairet-Coello et al., 2009) containing insulin $(10 \mu \mathrm{g} / \mathrm{ml})$, bFGF (10 ng/ml), and BDNF (30 ng/ml; PeproTech) with PACAP38 (10 nM; American Peptide) or its vehicle (0.01 N acetic acid). PACAP peptide was dissolved fresh for each experiment in sterile $0.01 \mathrm{~N}$ acetic acid to $100 \mu \mathrm{M}$ and further diluted in medium to a final concentration of $10 \mathrm{~nm}$. Preliminary PACAP dose-response studies (5-30 nM) indicated that maximal mitogenic effects were obtained at $10 \mathrm{nM}$. To study the PLC pathway, cells were plated in medium containing the PLC-specific antagonist U-73122 (1-[6[[(17 $\beta)$-3-methoxyestra-1,3,5(10)-trien-17-yl] amino]hexyl]-1 $H$-pyrrole-2,5-dione) ( $2 \mu \mathrm{M}$; Enzo) or inactive isomer U-73343 (1-[6-((17 $\beta$-3-methoxyestra-1,3,5(10)-trien-17-yl)amino)hexyl]-2,5pyrrolidine-dione) (2 $\mu \mathrm{M}$; Enzo), and after $30 \mathrm{~min}$, vehicle $(0.01 \mathrm{~N}$ acetic acid) or PACAP (10 nM) was added. For retinoic acid (RA) experiments, cells were incubated with either all trans-RA ( $30 \mathrm{~nm}$ ) (Sigma) or ethanol vehicle. RA was dissolved in $100 \%$ ethanol to $30 \mathrm{~nm}$. For shRNA transfection using E10.5 rat precursors, $2 \mathrm{~h}$ after plating, $1 \mu \mathrm{g}$ of total DNA (mix of $0.5 \mu \mathrm{g}$ of hop shRNA \#1 and $0.5 \mu \mathrm{g}$ of hop shRNA \#2; see below) were transfected using Lipofectamine 2000 (Invitrogen) for $5 \mathrm{~h}$ as described previously (Tury et al., 2011). BrdU was added at $22 \mathrm{~h}$, and cells were fixed at $24 \mathrm{~h}$.

Expression vectors. To knockdown PAC1hop, the following oligonucleotides against different regions of rat PACl hop were synthesized, annealed, and ligated into the RNAi-Ready-pSiren-DNR-DsRedExpress vector (Clontech). This vector places shRNA expression under control of the human U6 promoter and DsRed expression under control of the CMV promoter (Francone et al., 2010). Based on approaches reported previously (Francone et al., 2010), the following sequences were targeted: PAClhop shRNA \#1, AATGCTACTGCAAGCCACA; PAC1hop shRNA \#2, GCTGCGTGCAGAAATGCTA; and scramble control, AATGCACGCTCAGCACAAG. To test efficacy of shRNAs, we examined their ability to reduce $\mathrm{PAC} 1$ protein expression from rat $\mathrm{PAC} 1$ hop and short vectors when cotransfected in cell lines.

pCI-neo-PAC1 short or hop constructs. Full-length rat PAC1 short or hop (Spengler et al., 1993) (gift from Dr. Journot, Montpellier, France) were inserted into mammalian expression vector pCI-neo (Promega) using EcoRI and NotI. This yields a pCI-neo PAC1 short or hop construct under control of the CMV promoter. All DNA constructs were verified by sequencing.

To test shRNA knockdown efficiency, pEAK-rapid human embryonic kidney 293 (HEK-293) cells were cultured in DMEM/F-12 containing 10\% fetal calf serum, $25 \mathrm{~mm}$ HEPES, and $1 \%$ penicillin/streptomycin for $2-3 \mathrm{~d}$ to $50-60 \%$ confluence. Cells were transfected with $1 \mu \mathrm{g}$ of plasmid DNA per 4 $\mathrm{cm}^{2}$ of control vector, $\mathrm{pCI}-\mathrm{neo}-\mathrm{PACl}$ short or hop, in the absence or presence of $0.5 \mu \mathrm{g}$ of PAC1 hop shRNA\#1 plus $0.5 \mu \mathrm{g}$ of PAC hop shRNA \#2 and $5 \mu \mathrm{l}$ of Lipofectamine $2000 \mathrm{in} 1 \mathrm{ml}$ of Optimem media (Invitrogen) for $5 \mathrm{~h}$, after which, cells were washed and incubated with growth media for another $48 \mathrm{~h}$. Cells were harvested for Western blot analysis and probed with a rabbit polyclonal anti-PAC1 IgG (H-55; catalog \#30018; Santa Cruz Biotechnology) raised against the $\mathrm{N}$-terminal extracellular domain that recognizes both rodent and human receptor proteins.

Immunocytochemistry. For triple immunofluorescence, cells were fixed in 4\% PFA for $20 \mathrm{~min}$ at 2, 24, or $48 \mathrm{~h}$ after plating, washed with PBS three times, and incubated with anti-RC1 (1:1000; 40E-C; Developmental Studies Hybridoma Bank) [RC1 recognizes an intermediate filament antigen in neuroepithelial cells and radial glial cells (Culican et al., 1990; Malatesta et al., 2003), currently considered a phosphorylated vimentin], anti-nestin (1:400; Millipore Bioscience Research Reagents), anti- $\beta$-III tubulin (TuJ1; 1:1000; Convance), anti-phospho-PKC (1:200; Cell Signaling Technology), or anti-phospho-ERK (1:1000; Cell Signaling Technology) in PBS containing 0.3\% Triton X-100 and 2\% NGS overnight, followed by respective Alexa Fluor secondary antibodies (Invitrogen) as described previously (Lu and DiCicco-Bloom, 1997; Mairet-Coello et al., 

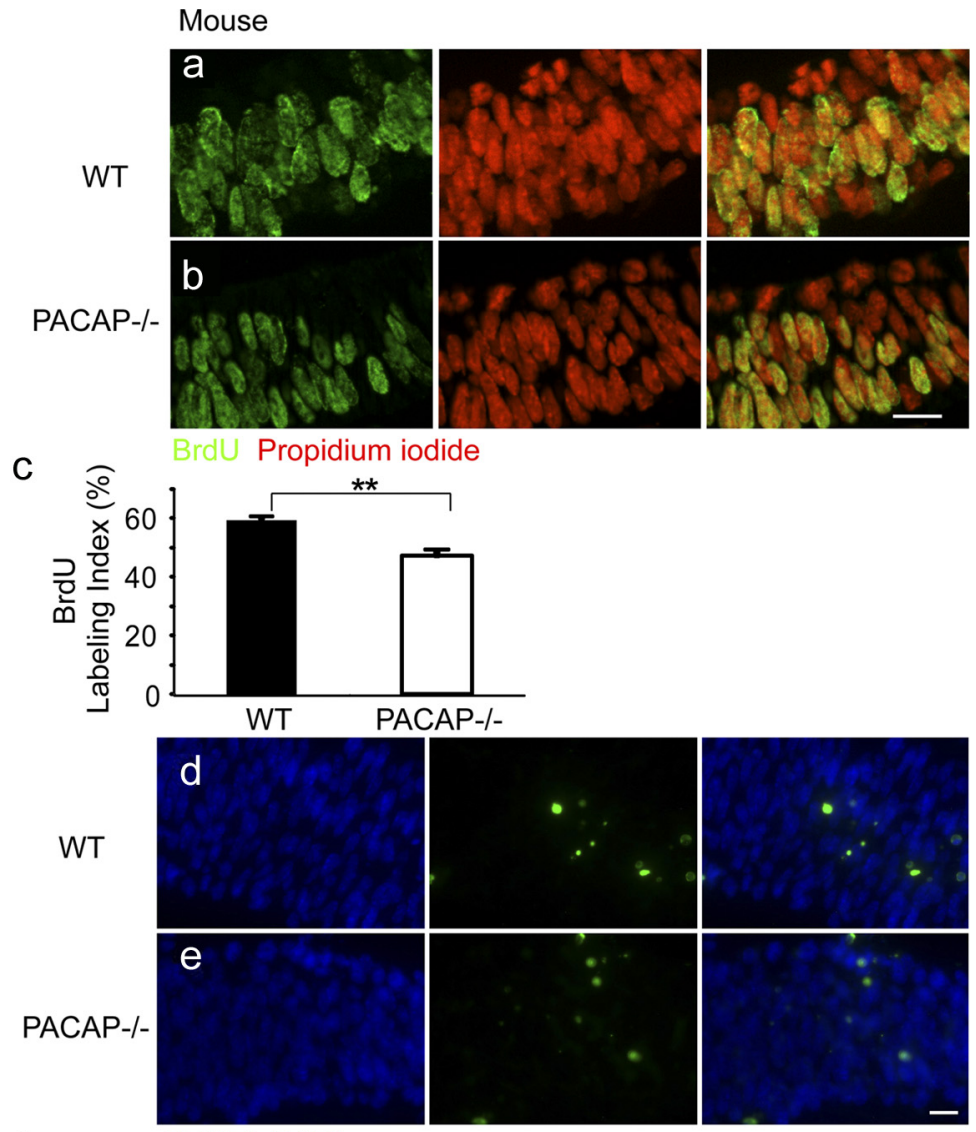

f

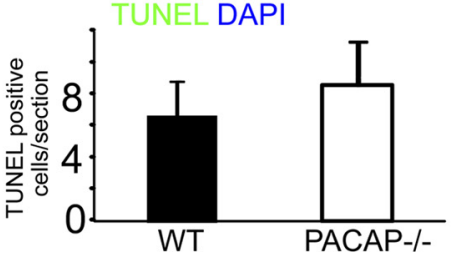

Figure 1. The telencephalic vesicles of E9.5 $P A C A P^{-1-}$ mice exhibit reduced S-phase labeling but no change in cell survival. $\boldsymbol{a}$, $\boldsymbol{b}$, BrdU immunohistochemical staining of E9.5 WT (a) and PACAP ${ }^{-1-}(\boldsymbol{b})$ VZ analyzed on coronal sections from the middorsolateral cortex. BrdU-positive cells (green) and total cells (PI; red) were counted blind in the VZ on these confocal images. $c$, Quantification of BrdU LI. PACAP ${ }^{-1-}$ exhibited a 47\% LI compared with 60\% in the WT. $\boldsymbol{d}, \boldsymbol{e}$, TUNEL staining of E9.5 WT (d) and PACAP ${ }^{-1-}$ (e) VZ. TUNEL-positive cells (green) and total cells (DAPl; blue) were counted blind. $\boldsymbol{f}$, Quantification of TUNEL-labeled cells per section. $n=3$ for each genotype. Results are expressed as mean \pm SEM. ${ }^{* *} p<0.01$. Scale bars, $10 \mu \mathrm{m}$.

2009). All culture dishes were provided a number so that the assessor was blind to experimental condition. The key was revealed only after data collection. Images were acquired with fluorescence microscope (Axiovert 200; Carl Zeiss) using $20 \times$ objective from 10 random fields per dish. Fluorescence image analysis was performed using AxioVisionLE software to determine mean fluorescence intensity. To define positive response, we set a fixed arbitrary threshold of fluorescence that was applied to all dishes within each experiment. TUNEL assay was performed using the Apoptosis Detection Kit (Millipore Bioscience Research Reagents).

DNA synthesis and cell division in vitro. Using 25,000 cells per well in 24-well plates, DNA synthesis was assessed using [ ${ }^{3} \mathrm{H}$ ] thymidine incorporation as a marker. A total of $1 \mu \mathrm{Ci} / \mathrm{ml}\left[{ }^{3} \mathrm{H}\right]$ thymidine (GE Healthcare) was added to 24 -well plates $4 \mathrm{~h}$ before harvesting at $24 \mathrm{~h}$. After aspiration of radiotracer-containing medium, cells were lifted with a trypsin-EDTA solution and collected onto filter paper using a semiautomatic cell harvester (Skatron). After adding luminating solution Eco-Lite (MP Biomedicals), radioactivity was measured by scintillation spectrophotometry. Alternatively, BrdU ( $10 \mu \mathrm{M}$ final) was added 2 or $4 \mathrm{~h}$ before culture termination to define the BrdU LI at $24 \mathrm{~h}$, the ratio of BrdU immunolabeled cells over total cells. Cells were counted blind under phase microscopy using $10 \times$ objective from 10 randomly selected fields in each of three dishes per group or from three $1-\mathrm{cm}$ strips of the dish, in fixed positions (stage micrometer) in the upper, middle, and lower thirds of the dish, representing $3 \%$ of the dish surface.

To determine whether cells entering $S$ phase in vitro subsequently underwent division between hours 24 and 36, a cohort of cells in each group was labeled using a $4 \mathrm{~h}$ BrdU pulse from hour 20 to 24 . After washing cells twice with PBS, one set of cultures was fixed immediately to enumerate cells in $S$ phase. A parallel set received culture media and were incubated another $12 \mathrm{~h}$, after which they were fixed. Both groups at both time points were processed for BrdU immunostaining in parallel. The absolute number of BrdU-labeled cells per field was determined by counting blind labeled cells in 10 randomly selected fields per dish at $10 \times$ objective. To estimate total cell numbers at 24 and $36 \mathrm{~h}$, the sum of all cells counted in 10 random fields per dish was obtained at $10 \times$ objective.

Flow cytometry. BrdU (10 $\mu \mathrm{M})$ was added to E10.5 cells at $20 \mathrm{~h}$. At $24 \mathrm{~h}$, cells were fixed with $70 \%$ ethanol and then processed for BrdU immunostaining as well as PI DNA staining, using standard methods as previously reported (DiCicco-Bloom et al., 1990). Samples were analyzed on a Beckman Coulter cell counter (FC500 Cytomics). The figures were generated using CXP software (Beckman Coulter).

Cell survival analysis. At 2 and $24 \mathrm{~h}, 15 \mu \mathrm{g} / \mathrm{ml}$ 7 fluorescein diacetate (FDA) (green fluorescence in living cells) (Vaudry et al., 2002c) and $15 \mu \mathrm{g} / \mathrm{ml}$ PI (red fluorescence in dead cells) were incubated with cells for $10 \mathrm{~min}$ as described previously (Mairet-Coello et al., 2009). At each time point, cells were counted blind under phase microscopy using $10 \times$ objective from 10 randomly selected fields in each of three dishes per group. Percentage cell survival was determined as the ratio of total green cells at $24 \mathrm{~h}$ over total green cells at $2 \mathrm{~h}$.

Quantitative reverse transcription-PCR. Total RNA was extracted from E10.5 and E14.5 rat cerebral cortices or from $24 \mathrm{~h}$ cultures of E10.5 cortical precursors (obtained from 50-75 embryos/isolation) using RNeasy Mini Kit (Qiagen). DNA was digested by 15 min DNase I treatment. RNA $(0.5 \mu \mathrm{g})$ was reverse transcribed with MMLV reverse transcriptase (Promega). Quantitative reverse transcription (qRT)-PCR was performed using PCR Master Mix (Applied Biosystems), and reactions were performed in an ABI Prism 7000 Sequence Detection system (Applied Biosystems) as described previously (Mairet-Coello et al., 2009). The sequences of the primers were as follows: PAC1 short forward, 5' - AGTCGAGCATCTACTTACGGC-3'; PAC1 short reverse, 5' -TTCC CTCTTGCTGACGTTCTC-3'; PAC1 hop forward, 5' -ACTTCAGCTG CGTGCAGAAATGC-3'; PAC1 hop reverse, 5'-GACGTTCTCTGGAG AGAAGGCAA-3'; cyclin D1 forward, 5' -GGCCCAGCAGAACATCGA T-3'; cyclin D1 reverse, 5' -GACCAGCTTCTTCCTCCACTTC-3'; cyclin D3 forward, 5' -TCTCTGCCCAGTGACCATCA-3'; cyclin D3 reverse, 5'-GGGCCCAAGACGTTTGG-3'; cyclin E forward, 5' -AGCCCCCTGA CCATTGTG-3'; and cyclin E reverse, 5'-TCGTTGACGTAGGCCACT TG-3'. Primers for rodent GAPDH were obtained from Applied Biosystems (proprietary sequences).

Primers worked with high specificity and nonspecific PCR were ruled out by observing a clear peak in the melting curves. cDNAs encoding PAC1 short or PAC1 hop1 were provided by Dr. Journot and purified as reported previously (Nicot and DiCicco-Bloom, 2001). PACAP isoform 
values are presented as fold difference compared with E10.5 hop mRNA levels, which were arbitrarily set at $100 \%$.

Western blot analysis. Proteins were extracted from $24 \mathrm{~h}$ E10.5 rat cortical precursors (50-75 embryos for each experiment). Equal amounts of proteins $(10-30 \mu \mathrm{g})$ were loaded on $12 \%$ SDSpolyacrylamide gels and were electrotransferred onto polyvinylidene difluoride membranes. After incubation with blocking buffer, filters were incubated overnight at $4^{\circ} \mathrm{C}$ with primary antibodies (Santa Cruz Biotechnology): anti-PAC1 (1:300; H-55), anti-cyclin D1 (1:500), anti-cyclin D2 (1: $1000)$, and anti-actin (1:1000), as described previously (Mairet-Coello et al., 2009). Incubations with horseradish peroxidase-conjugated secondary antibodies (1:1000) were performed for $1 \mathrm{~h}$ at room temperature, and visualization was performed using chemiluminescence (ECL; GE Healthcare). Autoradiographic films were analyzed using the Bio-Rad Gel Doc 2000 with Quantity One version 4.2.1 software (Bio$\mathrm{Rad})$. To control for loading, blots were stripped and reanalyzed for $\beta$-actin.

Measurement of intracellular calcium. Culture medium was removed from 96-well plates, and cortical precursor cells were washed with balanced salt solution, pH 7.2 (Pan et al., 2000). Cells were incubated with $\mathrm{Ca}^{2+}$ indicator Fluo-4 AM ( $3 \mu \mathrm{M}$; Invitrogen) for $30 \mathrm{~min}$ at $37^{\circ} \mathrm{C}$. After vehicle, PACAP38 $(10 \mathrm{~nm})$, or $\mathrm{KCl}$ (40 $\mathrm{mm}$ ) addition, fluorescence intensity was measured at a $37^{\circ} \mathrm{C} / 5 \% \mathrm{CO}_{2}$ atmosphere using excitation wavelength at $488 \pm 5 \mathrm{~nm}$ and emission wavelength at $515 \pm 5 \mathrm{~nm}$ using BD Pathway 855 BioImager with $20 \times$ objective (Olympus Plan fluo 0.75 numerical aperture). Images were acquired at $1 \mathrm{~s}$ intervals, and recording lasted for $110 \mathrm{~s}$ after adding reagents. The mean timedependent fluorescence intensity of individual cells was measured using NIH Image J software after background subtraction.

Statistical analyses. Data are expressed as mean \pm SEM. Statistical comparisons were made by unpaired Student's $t$ test or one-way ANOVA using Excel (Microsoft) and GraphPad Prism (GraphPad Software).

\section{Results}

\section{Deletion of the PACAP gene}

(ADCYAP1) results in decreased proliferation in the early embryonic $\mathrm{VZ}$ Previous studies indicate that PACAP in-

hibits cortical precursor proliferation at E13.5-E17.5 (Lu and DiCicco-Bloom, 1997; Suh et al., 2001; Nicot et al., 2002; Tury et al., 2011). To begin defining effects on early neurogenesis, we compared the proportion of cells in S phase in the VZ of WT and PACAP ${ }^{-1-}$ mice at E9.5 using BrdU immunohistochemistry (Fig. 1). At E9.5, the rostral neural tube has closed to form the three primitive brain vesicles. The prosencephalic vesicle consists of only the VZ and exhibits a four- to five-cell-thick layer. The BrdU LI in the VZ of the PACAP ${ }^{-1-}$ prosencephalon was reduced to $47 \%$ compared with the WT control LI of $60 \%$, suggesting that PACAP has a proliferative role at this age. Because the reduction of BrdU LI in the PACAP ${ }^{-/-}$mice may result from decreased cell survival, we performed TUNEL staining in the same region (Fig. $1 d-f)$. There was no statistically significant difference in TUNEL-
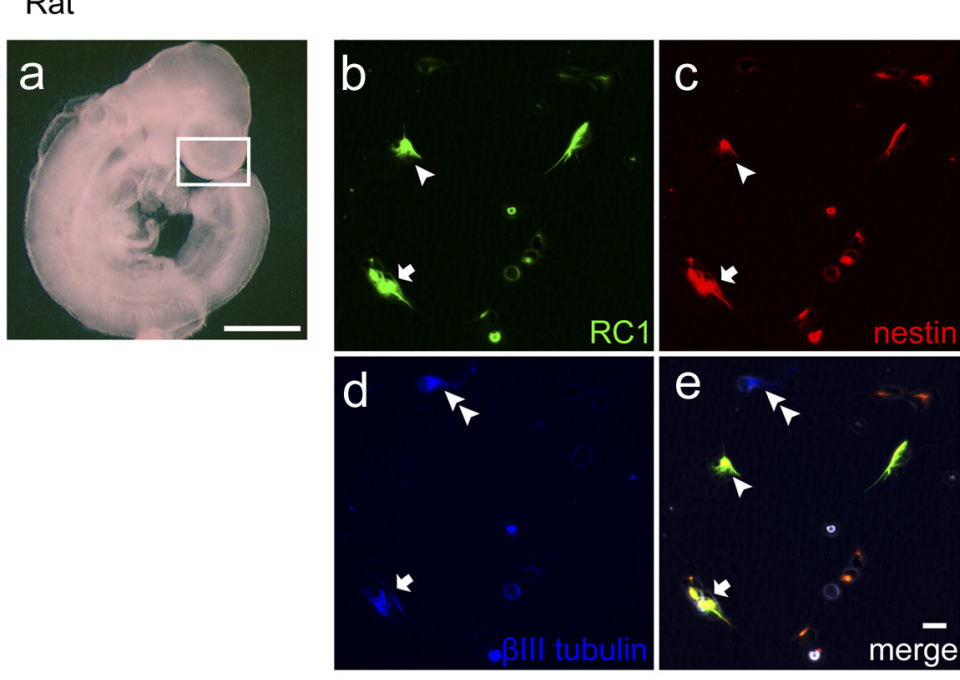

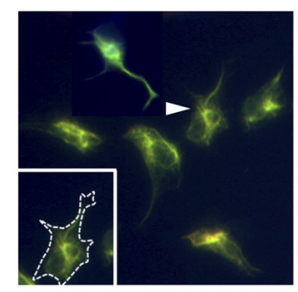

E10.5
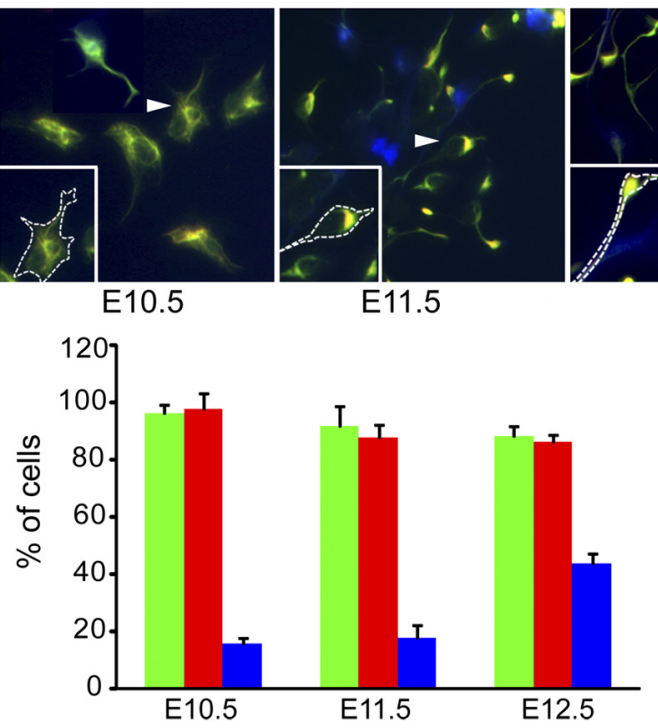

E11.5

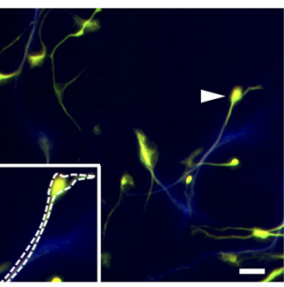

E12.5
Figure 2. Characterization of a new precursor culture model. $\boldsymbol{a}$, Photomicrograph of a rat embryo at E10.5. White box indicates the telencephalic region dissected for culture. Scale bar, $1000 \mu \mathrm{m} . \boldsymbol{b}-\boldsymbol{f}$, Cortical cultures consist of neural precursors and differentiating neurons at $24 \mathrm{~h}$. Immunocytochemical analysis of cell-type-specific markers: $\boldsymbol{b}, \mathrm{RC}$; $\boldsymbol{c}$, nestin; $\boldsymbol{d}, \boldsymbol{\beta}$-III tubulin; $\boldsymbol{e}$, merged. Arrowheads indicate RC1 and nestin double-positive cells, double arrowheads indicate $\beta$-III tubulin-positive cells, and arrows indicate triple-positive cells. Scale bar: $\boldsymbol{e}, 10 \mu \mathrm{m}$. $\boldsymbol{f}$, Examples of typical triple immunostaining of E10.5-E12.5 precursors are Bottom, The percentage of labeled cells at $24 \mathrm{~h}$ is quantified. Note that a greater proportion of cells exhibit $\beta$-III tubulin at E12.5 when we observe many cells with extended processes. Data were obtained from three separate experiments, $100-150$ cells analyzed per staining. Scale bar, $10 \mu \mathrm{m}$.

positive cells between WT and $P A C A P^{-/-}$, suggesting that cell survival was not affected. However, to further analyze PACAP function at this age, we established a novel culture model of young precursors to more directly define PACAP effects during early neurogenesis.

\section{Characterization of precursor cell culture}

At E10.5, the rat cerebral cortex (similar to E9.5 mouse; Fig. 1) consists primarily of $\mathrm{VZ}$ precursors, with the majority proliferating (Fig. 2a). To maintain precursor survival, we used defined media containing multiple trophic factors, including insulin, bFGF, and BDNF. In the absence of trophic factors, early precursors were unable to survive for $20 \mathrm{~h}$ even when incubated in Neurobasal plus B27 media (data not shown). In this model, $96.2 \pm 3.2 \%$ of the E10.5 precursors expressed RC1 and $98.1 \pm$ 

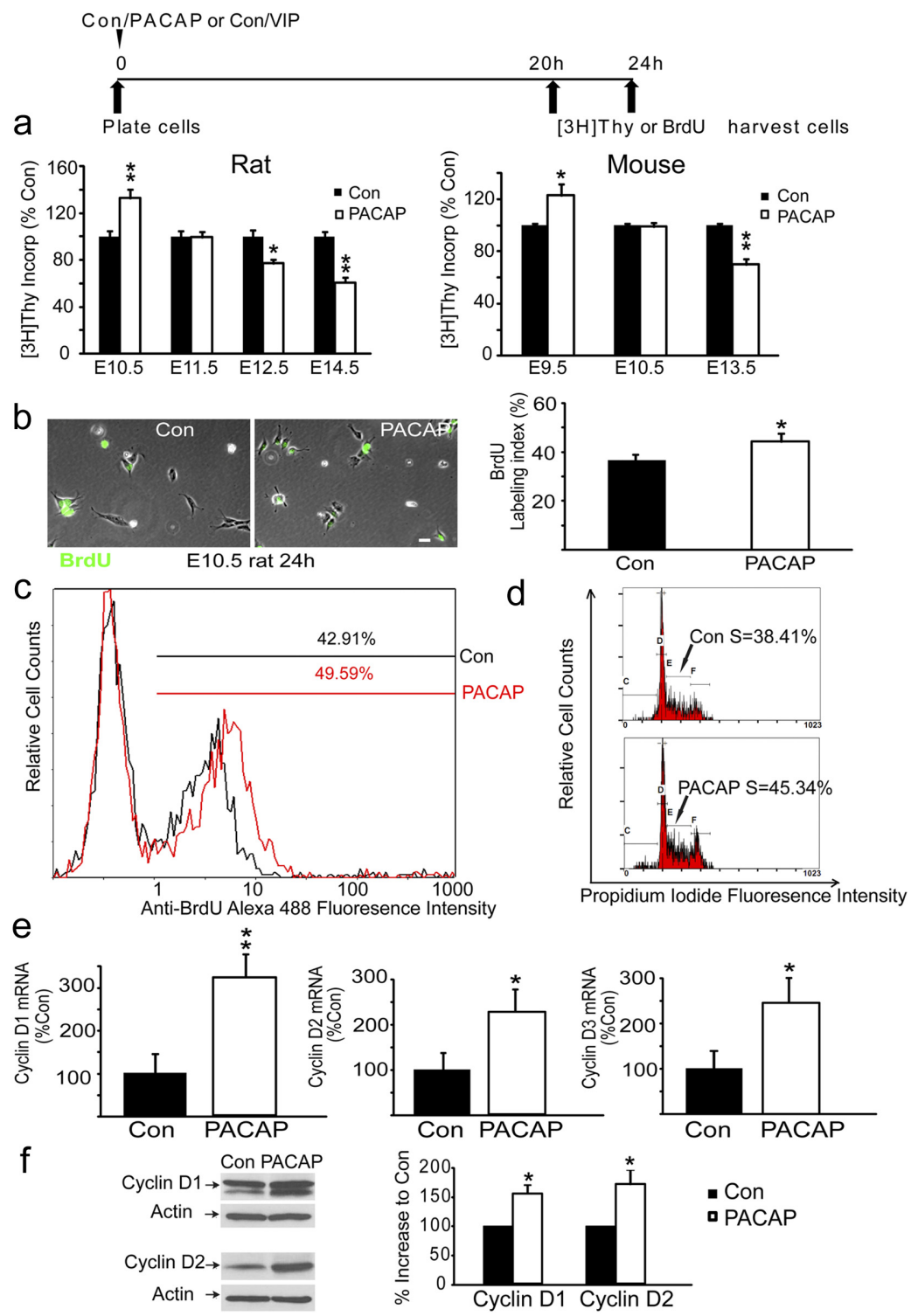

Figure 3. PACAP exhibits age-dependent effects on DNA synthesis and promotes $G_{1}$ cyclins and $G_{1} / S$-phase progression in vitro. $\boldsymbol{a}$, Effects of PACAP exposure on DNA synthesis at $24 \mathrm{~h}$ in rat and mouse precursors from different ages. The timeline above the graphs details the experimental paradigm. DNA synthesis was assessed using $\left[{ }^{3} H\right]$ thymidine incorporation. Data were obtained from five experiments for each species, using three wells ( 25,000 cells per well) per group for each experiment. Data are expressed as percentage control: control (Con) values ranged from 4000 from 12,000 cpm. ${ }^{*} p<0.05$, ${ }^{* *} p<0.01$. b, PACAP treatment increases the proportion of E10.5 rat precursor cells engaged in S phase. BrdU-positive cells (green) and total cells (phase) were counted in 10 randomly selected fields. Scale bar, $10 \mu \mathrm{m}$. PACAP exposure increased the BrdU LI from $36 \%$ in control to $45 \%$ in the PACAP group at $24 \mathrm{~h}$. c, Flow cytometric analysis of BrdU immunolabeling of control and PACAP-treated E10.5 rat precursors. PACAP treatment increased S-phase labeling from 43 to $50 \%$ at $24 \mathrm{~h}$. d, Flow cytometric analysis of DNA content using Pl indicates that more cells were engaged in $S$ phase in response to PACAP exposure at $24 \mathrm{~h}$. $\boldsymbol{e}$, Real-time PCR analysis indicates that PACAP treatment increased cyclin D1 mRNA by $221 \%$, cyclin mRNA D2 by $116 \%$, and cyclin mRNA D3 by $118 \%$, but not cyclin $\mathrm{E}$ (data not shown), at $24 \mathrm{~h}$. Data were obtained using total RNA (50-75 embryos for each isolation) obtained from three separate experiments.f, PACAP treatment increased protein levels of cyclin D1 by $58 \%$ and D 2 by $74 \%$ at $24 \mathrm{~h}$, as defined by Western blot analysis. Quantifications were performed on three to four separate blots for each protein, cyclins D1, D2, D3, and E.

ished precursor markers compared with the younger age $(92.1$ and $88.4 \%$ expressing $\mathrm{RC} 1$ and 87.9 and $86.7 \%$ expressing nestin, respectively) and an increase in neuronal protein (18.1 and $43.9 \% \beta$-III tubulin, respectively) (Fig. 2f), suggesting age-dependent differences in developmental capacity at the time of plating, as reported previously (Romito-DiGiacomo et al., 2007).

\section{PACAP elicits age-dependent effects on} DNA synthesis in both rat and mouse

To define PACAP proliferative activity, we examined effects of exogenous PACAP using rodent cortical precursors isolated at different embryonic ages under identical culture conditions. Initial studies used rat, rather than mouse, precursors based on the more extensive previous work in the former model (Lu and DiCicco-Bloom, 1997; Vaccarino et al., 1999; Nicot and DiCicco-Bloom, 2001; Suh et al., 2001; Carey et al., 2002; Noctor et al., 2004; Schaar et al., 2004; Malagelada et al., 2011; Tury et al., 2011). In E10.5 rat precursors incubated for $24 \mathrm{~h}$, PACAP exposure elicited a 33\% increase in $\left[{ }^{3} \mathrm{H}\right]$ thymidine incorporation (Fig. 3a, rat), indicating that the peptide increased the amount of DNA synthesis. However, in cultures isolated from embryos just $1 \mathrm{~d}$ older (E11.5), PACAP elicited no effects on $\left[{ }^{3} \mathrm{H}\right]$ thymidine incorporation. Subsequently, at E12.5 and E14.5, PACAP inhibited mitosis by 23 and 39\% respectively, suggesting that mitogenic effects are developmental stage dependent (Fig. 3a). The anti-mitogenic effects elicited at older ages are consistent with previous studies that used media lacking the panel of trophic factors ( $\mathrm{Lu}$ and DiCicco-Bloom, 1997; Nicot and DiCicco-Bloom, 2001; Suh et al., 2001; Tury et al., 2011).

To allow comparison with genetic deletion mutants, we extended study to the mouse, examining comparable developmental stages, E9.5-E13.5. In E9.5 mouse precursors, PACAP exposure increased $\left[{ }^{3} \mathrm{H}\right]$ thymidine incorporation by $23 \%$ compared with vehicle, stimulation that was comparable with that in E10.5 rat. Similarly, PACAP elicited no effect at E10.5 (E11.5 in rat) and induced a 30\% decrease on E13.5 (E14.5 in rat), suggest-

$5.4 \%$ expressed nestin at $24 \mathrm{~h}$, both markers of neural precursors (Fig. $2 b, c) ; 15.6 \pm 2.2 \%$ of the cells expressed $\beta$-III tubulin (TuJ1), an early marker of postmitotic neurons (Fig. $2 d, e$ ), and this percentage increased to $19.8 \pm 2.9 \%$ at $48 \mathrm{~h}$, suggesting the differentiation potential of these precursors. In contrast, neither 24 nor $48 \mathrm{~h}$ cultures exhibited glial antigens, including markers of astrocytes, glial fibrillary acidic protein, or the oligodendrocyte progenitor NG2 (data not shown). Under identical conditions, cultures of E11.5 and E12.5 precursors at $24 \mathrm{~h}$ exhibited dimin- ing that mitogenic effects are developmental stage dependent in both species (Fig. 3a, mouse). However, because PACAP elicited similar effects in both species, we continued our studies using rat cortical precursors because they are more convenient to isolate and maintain and allow comparison with extensive previous studies.

Because PACAP might potentially activate three related receptors, including PAC1, VPAC1, and VPAC2, to elicit mitogenic stimulation, we examined the effects of related peptide, vasoac- 


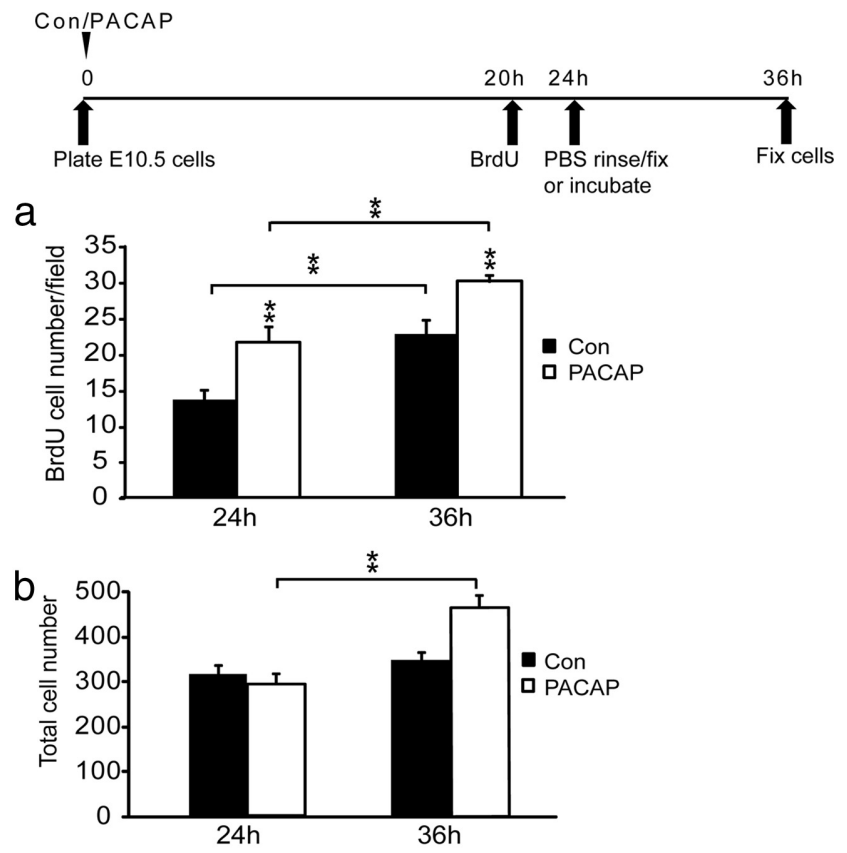

C

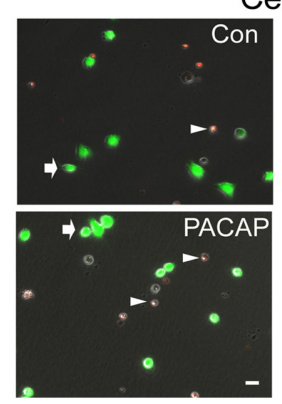

Cell Survival $24 \mathrm{~h}$

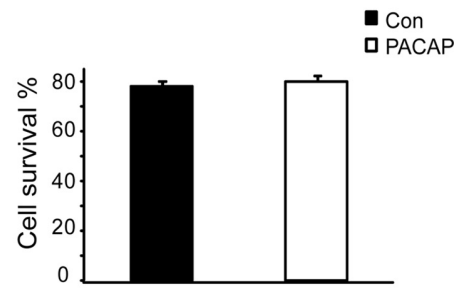

Figure 4. Effects of PACAP on cell division, cell number, and cell survival. $a$, Quantification of total BrdU-positive cells: vehicle [control (Con)] or PACAP was added at cell plating. Precursors in $S$ phase were labeled with BrdU from hours 20 to 24 , and one group of sister control and PACAP cultures were fixed at $24 \mathrm{~h}$. A parallel set of control and PACAP cultures were rinsed twice with PBS, incubated in fresh control or PACAP medium for another $12 \mathrm{~h}$, and then fixed at $36 \mathrm{~h}$. At $24 \mathrm{~h}, 59 \%$ more cells were in $S$ phase in the PACAP exposed group compared with control, consistent with increased BrdU $\mathrm{LI}$ in Figure 3b. At $36 \mathrm{~h}$, the number of BrdU-positive cells increased in both groups, indicating that cells that entered $S$ phase subsequently went on to divide. $\boldsymbol{b}$, Quantification of total cell number in control and PACAP-treated cultures at 24 and $36 \mathrm{~h}$. The $y$-axis corresponds to the total number of cells counted in 10 random fields. Whereas no difference in cell number among groups was observed at $24 \mathrm{~h}$, a $61 \%$ increase was detected in the PACAP group at $36 \mathrm{~h}$ compared with its $24 \mathrm{~h}$ value, suggesting cell proliferation. Note that there was no change in control cell numbers between 24 and $36 \mathrm{~h}$. $c$, Effects of PACAP on cell survival and cell death. PI and FDA were used to distinguish dead cells (arrowheads) and living cells (arrows), respectively. Scale bar, $10 \mu \mathrm{m}$. Percentage cell survival was determined as the ratio of FDA-stained cells at $24 \mathrm{~h}$ over $2 \mathrm{~h}$. Results are expressed as mean \pm SEM. ${ }^{*} p<0.05$, ${ }^{* *} p<0.01$. Data were derived from three different experiments, two dishes per group per experiment.

tive intestinal peptide (VIP), because at physiological concentrations, it activates only VPAC1 and VPAC2 receptors, having only low affinity for PAC1 (Arimura, 1992). VIP (10 nM) treatment did not elicit any change in DNA synthesis of E10.5 rat precursors at $24 \mathrm{~h}$ (control, $100 \pm 8.2 \%$; VIP, $107 \pm 6.4 \%$; mean [3H]thymidine incorporation, expressed as percentage control \pm SEM), suggesting that, if they are present, neither VPAC receptor links to mitogenic regulation at this stage. This also implies that PACAP acts via the PAC1 receptor at E10.5 to stimulate $\left[{ }^{3} \mathrm{H}\right]$ thymidine incorporation.

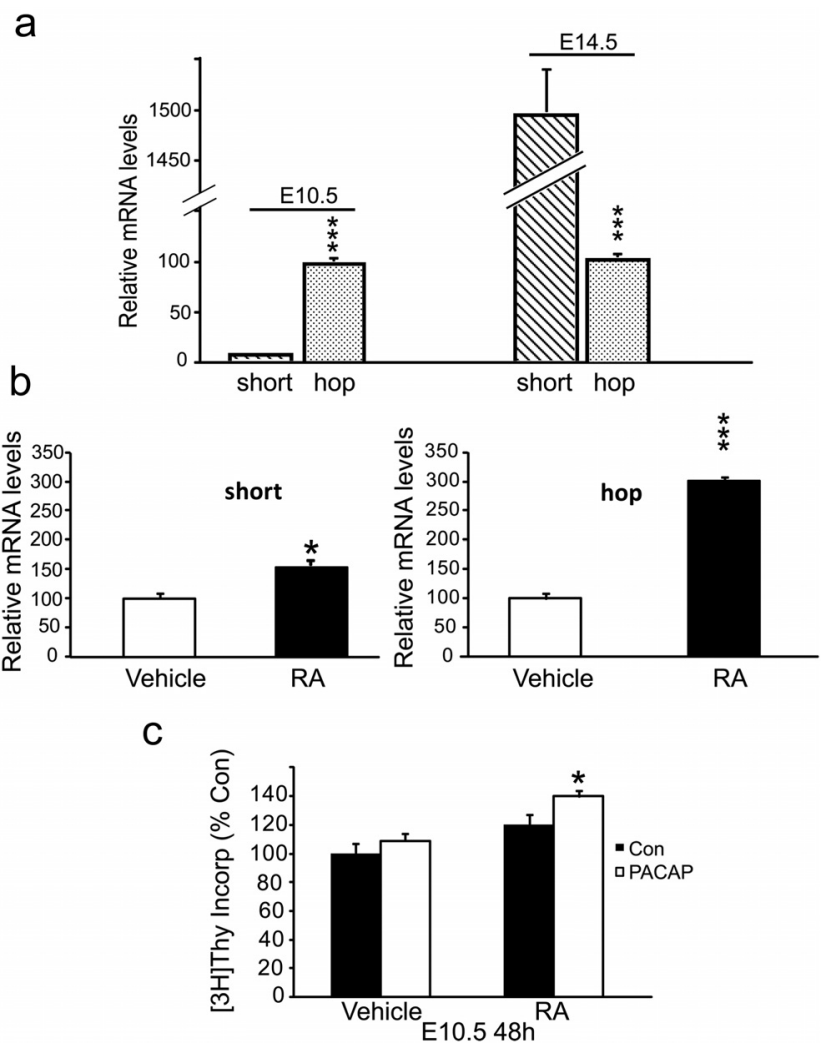

Figure 5. Developmental transition of $\mathrm{PAC1}$ receptor $\mathrm{mRNA}$ isoform expression during corticogenesis and regulation by RA. $\boldsymbol{a}$, AtE10.5, the level of the hop isoform is 24 -fold greater than short; at E14.5, short is 15 -fold greater than hop. Values are presented as fold difference when compared with the E10.5 hop mRNA levels arbitrarily set at 100. Values are representative of three experiments, three to eight animals per group for each experiment. ${ }^{* * *} p<0.001 . \boldsymbol{b}$, RA exposure increased differentially the short and hop isoforms at $24 \mathrm{~h}$, detected using real-time PCR. Data represent three experiments, two dishes per group, $n=6\left(2 \times 10^{6}\right.$ cells per dish $)$ for RNA quantification. c, E10.5 precursors were incubated with either vehicle (ethanol) or RA (30 $\mathrm{nm}$ ) at plating. At $24 \mathrm{~h}$, cultures received either PACAP vehicle (Con) or PACAP (10 nM), and DNA synthesis was assessed at $48 \mathrm{~h}$. In the presence of RA, PACAP increased precursor DNA synthesis, whereas the peptide had no effect in the RA vehicle group. Note that RA alone had no effect on DNA synthesis. Data represent three wells per group (25,000 cells per well) in each of three experiments for $\left[{ }^{3} \mathrm{H}\right]$ thymidine incorporation. ${ }^{*} p<0.05,{ }^{* * *} p<0.001$.

PACAP promotes $G_{1} / S$ progression and cell division without altering cell survival at E10.5

Although PACAP increased DNA synthesis by 33\% in E10.5 cultures (Fig. $3 a$ ), this effect may be attributable to either promoting $\mathrm{G}_{1} / \mathrm{S}$ progression or, alternatively, preventing precursor cell death, because PACAP has well-documented neurotrophic activity (Waschek, 2002; Ohta et al., 2006; Vaudry et al., 2009). To begin addressing this question, E10.5 precursors engaged in S phase were labeled with a $4 \mathrm{~h}$ BrdU pulse to define the LI at $24 \mathrm{~h}$. After PACAP exposure, the BrdU LI was increased from $36 \%$ in control to $45 \%$ in the PACAP group, as assessed by immunocytochemistry of precursor cultures (Fig. $3 b$ ), consistent with PACAP increasing $G_{1} / S$ progression. To verify these changes, we also used alternative measures, specifically, flow cytometric analysis of cultured cells after $24 \mathrm{~h}$ incubation. Consistent with BrdU immunocytochemistry, BrdU flow cytometry indicated that PACAP treatment also increased the S-phase percentage from $43 \%$ in control to $50 \%$ after peptide exposure (Fig. $3 c$ ). Moreover, by analyzing single-cell levels of PI that quantitatively binds DNA, we also observed that the fraction of cells engaged in S phase increased from $38 \%$ in control to $45 \%$ in the PACAP- 


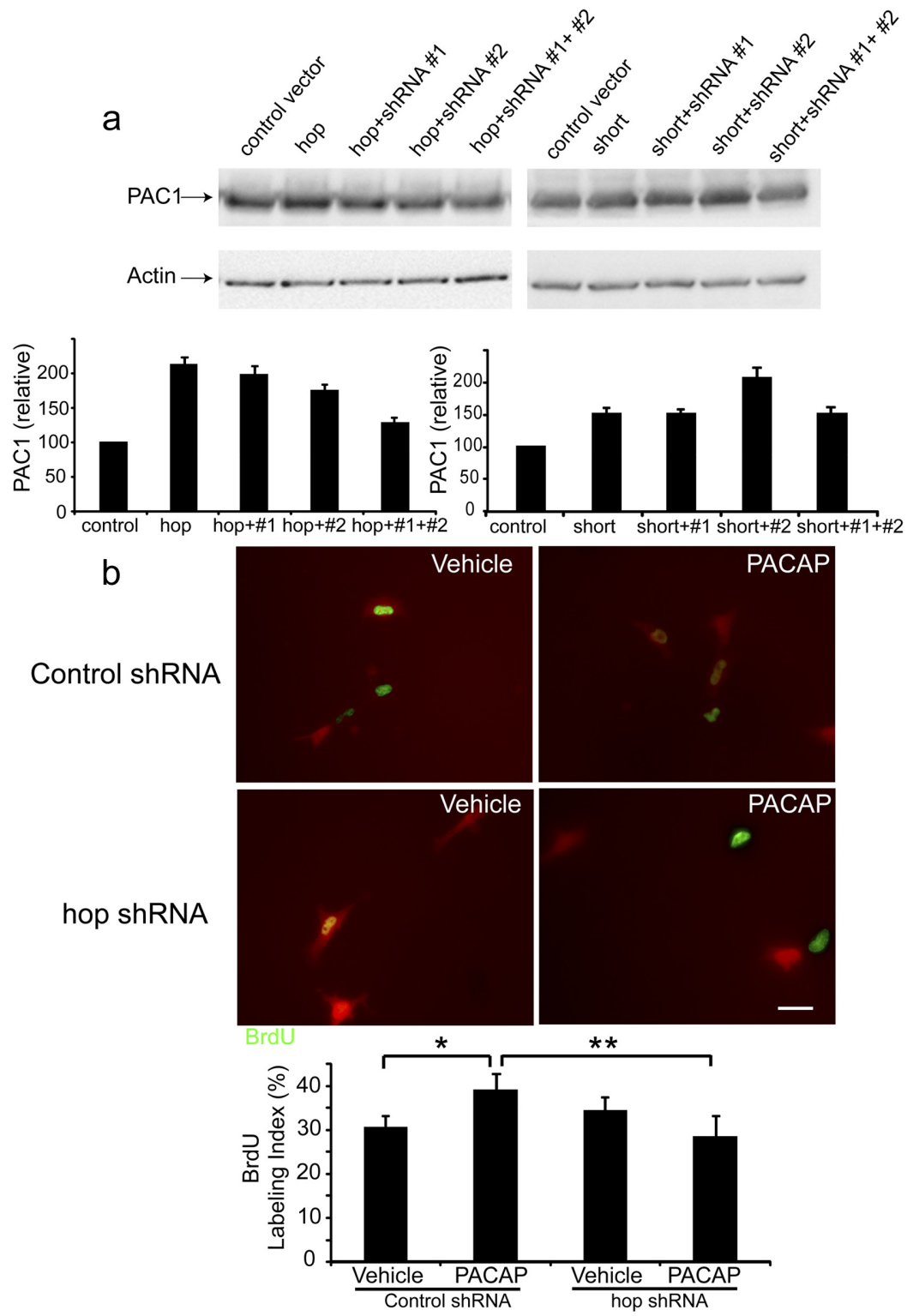

Figure 6. shRNA knockdown of PAC1 hop expression. $\boldsymbol{a}$, pEAK rapid HEK-293 cells were transfected with control vector or full-length rat hop or short expression vectors without and with hop shRNAs. PAC1 antibody detects both hop and short proteins including both human as well as rat. Data were derived from three experiments. Transfection efficiency was $50-60 \%$ per group. $\boldsymbol{b}$, E10.5 precursors were transfected with either control shRNA or both hop shRNAs $2 \mathrm{~h}$ after plating, in the absence of PACAP (Vehicle) or the presence of PACAP (10 nM). BrdU was added at $22 \mathrm{~h}$, and cells were fixed at $24 \mathrm{~h}$. Cells that were transfected with control shRNA or hop shRNAs can be visualized by red fluorescence. The four groups were analyzed by one-way ANOVA, followed by Tukey's multiple comparison test. Sixtransfections from three experiments were performed, and transfection efficiency was $10-15 \%$ in E10.5 precursors. The number of cells analyzed from each experiment was $20-35$ per dish. Scale bar, $10 \mu \mathrm{m} .{ }^{*} p<0.05,{ }^{* *} p<0.01$

treated cultures (Fig. 3d). This 7\% increase represents a change of magnitude comparable with that observed with both BrdU-based methods (Fig. 3b, a 9\% increase; $c$, a 7\% increase) and is consistent with the peptide increasing $\mathrm{G}_{1} / \mathrm{S}$-phase progression in vitro.

If PACAP enhanced $\mathrm{G}_{1}$-to-S phase progression, the peptide might act via cell cycle machinery, especially $G_{1}$ cyclins. Although limited tissue availability hampered analyses, we began examining this issue by performing real-time PCR and found that cyclins D1, D2, and D3 (but not cyclin E; data not shown) were all increased at $24 \mathrm{~h}$ by PACAP exposure of E10.5 precursors (Fig. $3 e$ ). These changes in D cyclins at the transcriptional level encouraged us to examine PACAP effects at the translational level as well, by performing Western blot analyses using the very limited tissues from E10.5 cortices. Consistent with the real-time PCR results, PACAP also increased cyclin D1 and D2 protein expression levels by 58 and $74 \%$ respectively (Fig. 3f), suggesting that PACAP upregulates $G_{1} D$ cyclins to promote $G_{1} /$ S-phase progression.

To determine whether cells engaged in $S$ phase were able to complete mitosis and divide, we labeled a cohort of precursors by BrdU exposure from 20 to $24 \mathrm{~h}$, and, after PBS washes, cells were either fixed immediately to enumerate cells in $\mathrm{S}$ phase or were incubated another $12 \mathrm{~h}$ in either control or PACAP-containing media. If cells that were engaged in $S$ phase (incorporated BrdU) at $24 \mathrm{~h}$ subsequently underwent division, the absolute number of BrdU-labeled cells would increase from 24 to $36 \mathrm{~h}$. Indeed, at $36 \mathrm{~h}$, both control and PACAP groups demonstrated an increase in BrdU-positive cells, indicating that cells successfully underwent division, with the PACAP group producing more new cells than control (Fig. 4a).

To examine the potential role of cell survival, we assessed the total numbers of cells by phase microscopy as well as by using the FDA/PI assay. At $24 \mathrm{~h}$, when the BrdU LI was increased by PACAP (Fig. $3 b$ ), total cell numbers were not different between control and PACAP exposed cultures (Fig. 4b, $24 \mathrm{~h}$ ), consistent with PACAP promoting S-phase entry. Furthermore, there was no difference at $24 \mathrm{~h}$ in cell survival among groups compared with the number of cells $2 \mathrm{~h}$ after plating (Fig. 4c), suggesting that PACAP did not exhibit trophic activity during this period. However, although there were no differences in control and PACAP group cell numbers or cell survival at $24 \mathrm{~h}$, differences did emerge at $36 \mathrm{~h}$. The number of cells in control media at $36 \mathrm{~h}$ was similar to its $24 \mathrm{~h}$ value (Fig. $4 b$, compare Con $24 \mathrm{~h}$ to Con $36 \mathrm{~h}$ ). In contrast, the PACAPtreated group displayed a $61 \%$ increase in total cells compared with its $24 \mathrm{~h}$ value (Fig. 4b, PACAP $36 \mathrm{~h}$ ), suggesting that enhanced S-phase entry induced by PACAP at $24 \mathrm{~h}$ resulted in more neurogenesis $12 \mathrm{~h}$ later. It should be noted that, although both control and PACAP-treated groups exhibited S-phase entry and division of these labeled cells, i.e., cell division, (Fig. 3a), the total cell population did not necessarily increase in both groups (Fig. $3 b$ ). We know that there is ongoing cell death in both groups, with only $\sim 80 \%$ of plated cells surviving at $24 \mathrm{~h}$ (Fig. 3c). We suspect that the enhanced proliferation in the PACAP group exceeded the losses that are ongoing in the model. In aggregate, these data suggest that PACAP promotes precursor proliferation by increasing the proportion of cells that enter $S$ phase and complete cell division. 


\section{Developmental transition of PAC1 receptor isoform expression during neurogenesis}

Because PACAP elicited opposing effects on proliferation of precursors at different ages, we speculated the effects may reflect expression of distinct PAC1 isoforms. Thus, we examined expression of short and hop isoforms in E10.5 and E14.5 rat cortices using traditional RT-PCR (data not shown) and found that both variants were present, consistent with previous studies (Waschek et al., 1998; Zhou et al., 2000; Suh et al., 2001). To quantify stagedependent expression of the isoforms, we performed qRT-PCR. Using standard curves for both short and hop cDNAs, we assessed short and hop mRNA expression levels at E10.5 and E14.5. There was 24-fold greater expression of the hop than the short isoform at E10.5 (Fig. 5a, left). In contrast, by E14.5, the short isoform mRNA was upregulated markedly, whereas hop isoform changed little, reversing the ratio, so that short was 15 -fold greater than hop (Fig. 5a, right). The developmental transition in the ratio of PAC1 isoform mRNAs suggested that change in their expression may underlie the stage-specific mitogenic effects of PACAP.

\section{RA treatment maintains hop isoform expression and PACAP mitogenic activity}

The foregoing data suggest that expression of the hop isoform, known to activate PLC pathways, contributes to PACAP mitogenic stimulation in early precursors. Indeed, in E14.5 precursors, this stimulatory mechanism was established by overexpressing the hop isoform using transfection (Nicot and DiCicco-Bloom, 2001). To examine E10.5 precursors, we first asked whether a stimulus that promoted hop expression would also sustain PACAP mitogenic stimulation during development. We explored several hormone pathways known to affect early neurogenesis, including steroids and RA (Studer et al., 1994; Haskell and LaMantia, 2005), because the latter is known to modulate PAC1 expression levels (Waschek et al., 1997). To examine RA effects, E10.5 rat precursors were incubated with vehicle (ethanol) or RA (30 nM) for $24 \mathrm{~h}$, and real-time PCR was performed. RA treatment increased the levels of the hop isoform threefold, whereas the short isoform was only enhanced by $50 \%$ (Fig. $5 b$ ). To define the effects of PACAP after altering the receptor isoform ratio, we then added PACAP or its vehicle for another $24 \mathrm{~h}$ and measured DNA synthesis. It should be noted that, after $24 \mathrm{~h}$ in culture, E10.5 precursors may undergo the same transition in mitogenic response as precursors in vivo: E10.5 precursors first incubated for $24 \mathrm{~h}$ exhibited no response to addition of PACAP (Fig. $5 c$, vehicle). These data may suggest that incubation of E10.5 precursors allows them to become developmentally equivalent to E11.5 in PACAP response (Fig. $3 a$ ). In contrast, in the RA-treated group in which the hop isoform exceeded the short isoform, PACAP exposure increased DNA synthesis by $21 \%$ (Fig. $5 c$, RA), indicating that the increased hop/short ratio correlates with PACAP mitogenic stimulation. Conversely, RA treatment alone did not stimulate DNA synthesis (Fig. $5 c$ ). Although RA is normally a potent inducer of neuronal differentiation and not of proliferation during development, it surprisingly appears to serve a different function in our culture system, conferring a sensitivity to a pro-mitotic action of PACAP. Regardless, to more directly assess the role of the hop receptor isoform to PACAP stimulation, we turned to molecular approaches.

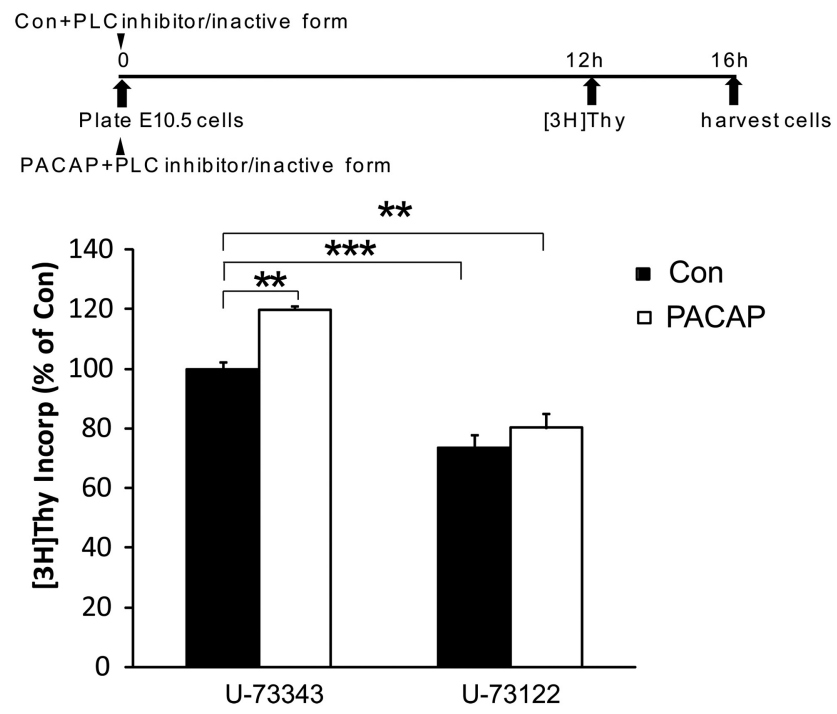

Figure 7. The role of PLC activation in the pro-mitogenic effects of PACAP at E10.5. In the presence of the inactive analog U-73343 $(2 \mu \mathrm{m})$ for $16 \mathrm{~h}$, PACAP increased DNA synthesis by $22 \%$, whereas the peptide-induced increase in DNA synthesis was blocked by the PLC antagonist U-73122 (2 $\mu \mathrm{M})$. All data bars are normalized to the control treatment (vehicle) in the presence of inactive analog U-73343, which was arbitrarily set at $100 \%$. Control (Con) values ranged from 2800 to $7500 \mathrm{cpm}$. The four groups were analyzed by one-way ANOVA, followed by Tukey's multiple comparison test. Data were derived from four experiments, three wells per group for each experiment. ${ }^{* *} p<0.01,{ }^{* * *} p<0.001$.

\section{Knockdown of hop expression blocks the pro-mitogenic activity of PACAP}

To examine whether high levels of hop expression are required for PACAP mitogenic stimulation in early precursors, we designed two hop shRNAs to rat PAC1hop. To first define the efficacy of the hop shRNAs, we examined their effects on rat PAC1 hop and short expression vectors. These studies were performed in human HEK-293 cells, which only express human PAC1, likely the short isoform, which is not targeted by rat hop shRNAs. When the empty control vector was expressed in HEK-293 cells, the endogenous human PAC1 protein was observed (Fig. $6 a$, left) because the available PAC1 antibodies identify both rodent and human receptor proteins. Transfection of HEK-293 cells with the rat hop expression vector alone increased levels of total PAC1 protein twofold (Fig. $6 a$, left). When hop protein was coexpressed with either shRNA \#1 or shRNA \#2, the increased levels were modestly decreased, whereas transfections of both shRNAs reduced overexpressed proteins levels by $>75 \%$, approaching those of endogenous human PAC1 (Fig. $6 a$, left). In marked contrast, the hop shRNAs did not block rat PAC1 short isoform overexpression (Fig. $6 a$, right), suggesting the shRNAs specifically targeted hop-specific sequences. Therefore, we used the combination of both \#1 and \#2 shRNAs in neuronal cultures. We silenced hop expression in E10.5 precursors, in the absence or presence of PACAP for $24 \mathrm{~h}$, and compared BrdU LI to control shRNA. Control shRNA does not correspond to known rodent transcripts. The shRNA vector transfected cells were identified by red fluorescence from the pSiren-DNR-DsRed-Express vectors (Fig. 6b). In the control shRNA group, PACAP elicited a significant increase in BrdU LI compared with vehicle (vehicle, 30.8\%; PACAP, 39.3\%). In contrast, in the presence of hop shRNAs, PACAP no longer stimulated S-phase entry in early cortical precursors (Fig. 6b, quantification). The hop shRNA alone (vehicle) also had no effect compared with control shRNA vector, suggesting that ongoing S-phase entry does not depend on hop signaling. 
a

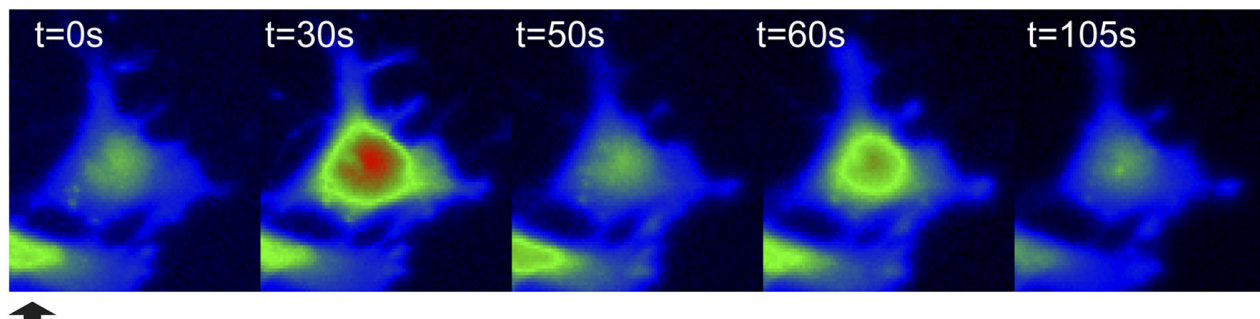

PACAP

b

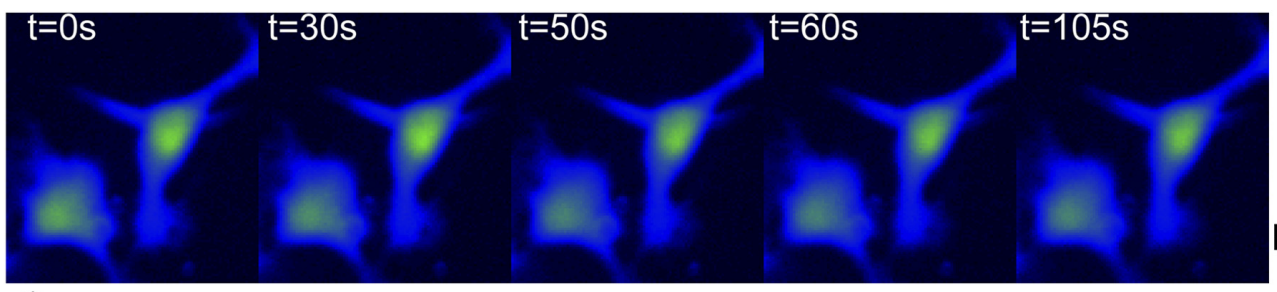

PACAP

C

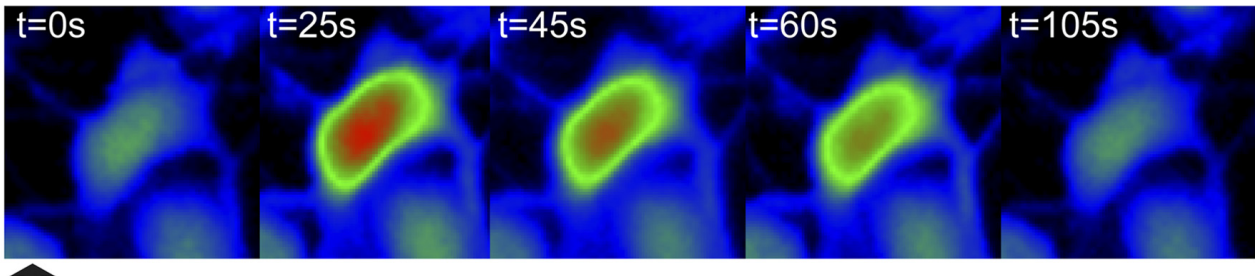

$\widehat{\mathrm{K}} \mathrm{Cl}$

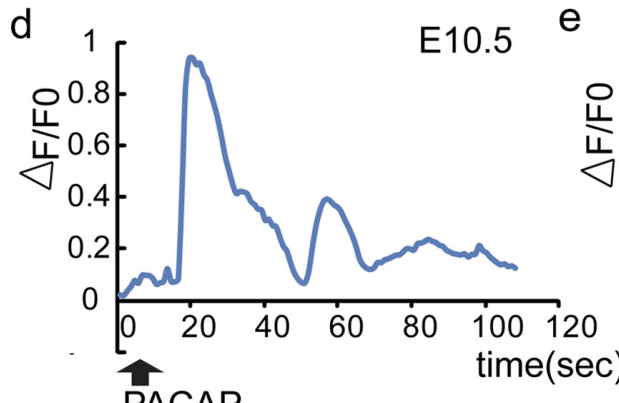

PACAP

f

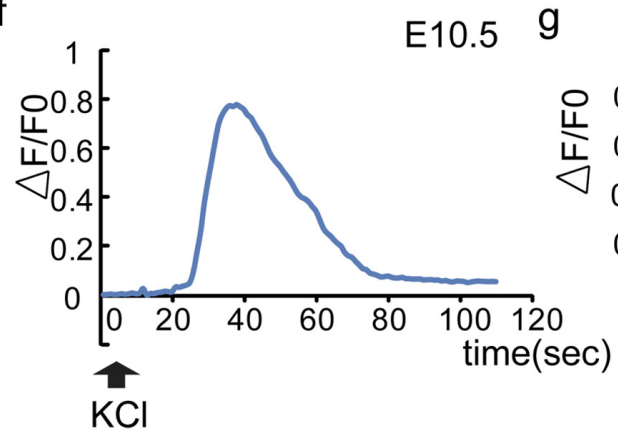

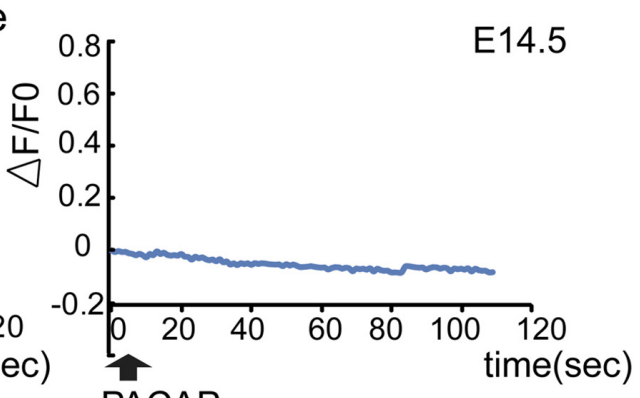

PACAP
E14.5

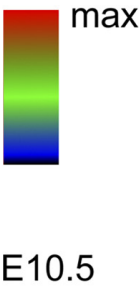

E14.5

\section{max}

0.5
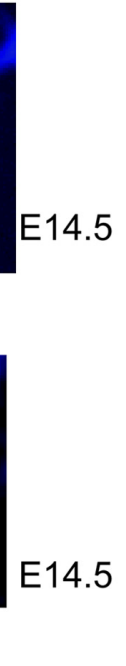
These observations suggest that PACAP mitogenic stimulation requires hop isoform expression. The blockade of PACAP stimulation in the presence of hop isoform knockdown is consistent with the converse experiment, in which enhanced hop expression elicited by RA treatment was associated with sustained PACAP stimulation of DNA synthesis (Fig. 5b,c). Because PACAP mitogenic activity through the hop isoform is known to depend on PLC pathways in other models, we next defined signaling transduction pathways activated by PACAP in young neural precursors.

\section{The role of PLC activation in the pro- mitogenic effects of PACAP}

In previous studies, PACAP mitogenic stimulation has been associated with activation of PLC that triggers the PKC pathway (Spengler et al., 1993; Lu et al., 1998; Nicot and DiCicco-Bloom, 2001). Because hop is the dominant receptor isoform at E10.5, we hypothesized that PLC activation may underlie PACAP stimulation. To investigate the role of PLC, we used the membrane-permeable PLCspecific inhibitor U-73122 and the inactive form U-73343 as a negative control. We incubated E10.5 cultures for $16 \mathrm{~h}$ only to avoid overall cell toxicity. In the presence of inactive drug, PACAP elicited a $22 \%$ increase in $\left[{ }^{3} \mathrm{H}\right]$ incorporation (an increase at $16 \mathrm{~h}$ that is proportional to $33 \%$ at $24 \mathrm{~h}$ ), whereas PACAP elicited no change when the PLC inhibitor was present, suggesting that pro-mitogenic effects were mediated via the PLC pathway (Fig. 7). Nonetheless, because of possible cell toxicity, we turned to more direct methods to detect cellular responses.

\section{PACAP induces intracellular calcium oscillations in E10.5 but not E14.5 cortical precursors}

Activated PLC can hydrolyze phosphatidylinositol 4,5-bisphosphate to generate two second messengers, diacyl glycerol (DAG) and inositol 1,4,5 trisphosphate ( $\left.\mathrm{IP}_{3}\right)$. The latter signal engages the $\mathrm{IP}_{3}$ receptor and elicits release of $\mathrm{Ca}^{2+}$ from the endoplasmic reticulum. $\mathrm{Ca}^{2+}$ is a well-known stimulator of proliferation in multiple systems (Berridge et al., 2000; Lewis, 2003; Weissman et al., 2004). Because the foregoing evidence raised the possibility of PLC signaling in PACAP mitogenic activity, we examined this downstream mediator, intracellular $\mathrm{Ca}^{2+}$. We monitored intracellular $\mathrm{Ca}^{2+}$ changes during PACAP activation in E10.5 and E14.5 cortical precursors in parallel using $\mathrm{Ca}^{2+}$ fluorescence indicator Fluo-4 AM. PACAP triggered an increase of cytosolic $\mathrm{Ca}^{2+}$ in most E10.5 cortical precursors, suggesting that the peptide activated the inositol phospholipid signaling pathway (Spengler et al., 1993; DiCicco-Bloom et al., 2000; Nicot and DiCicco-Bloom, 2001; Hegg et al., 2003) (Fig. 8a,d). Interestingly, the majority of E10.5 cells exhibited $\mathrm{Ca}^{2+}$ oscillations (Table 1). In contrast, PACAP did not elicit $\mathrm{Ca}^{2+}$ changes in E14.5 cortical precursors (Fig. 8b,e). However, both E10.5 and E14.5 precursors
Table 1. Calcium fluxes and oscillations in E10.5 and E14.5 cortical precursors

\begin{tabular}{llr}
\hline Calcium fluxes & E10.5 & E14.5 \\
\hline PACAP-responsive cells & 201 of $220(91 \%)$ & 7 of $306(2 \%)$ \\
PACAP-induced oscillations & 172 of $201(86 \%)$ & 0 of $306(0 \%)$ \\
KCl-responsive cells & 137 of $168(82 \%)$ & 398 of $412(97 \%)$ \\
\hline
\end{tabular}

Precursors were preloaded with $\mathrm{Ca}^{2+}$ fluorescent indicator Fluo-4 AM and recorded on a BD Pathway 855 Biolmager for 110 s after addition of PACAP (10 nM) or KCI ( $40 \mathrm{~mm})$.
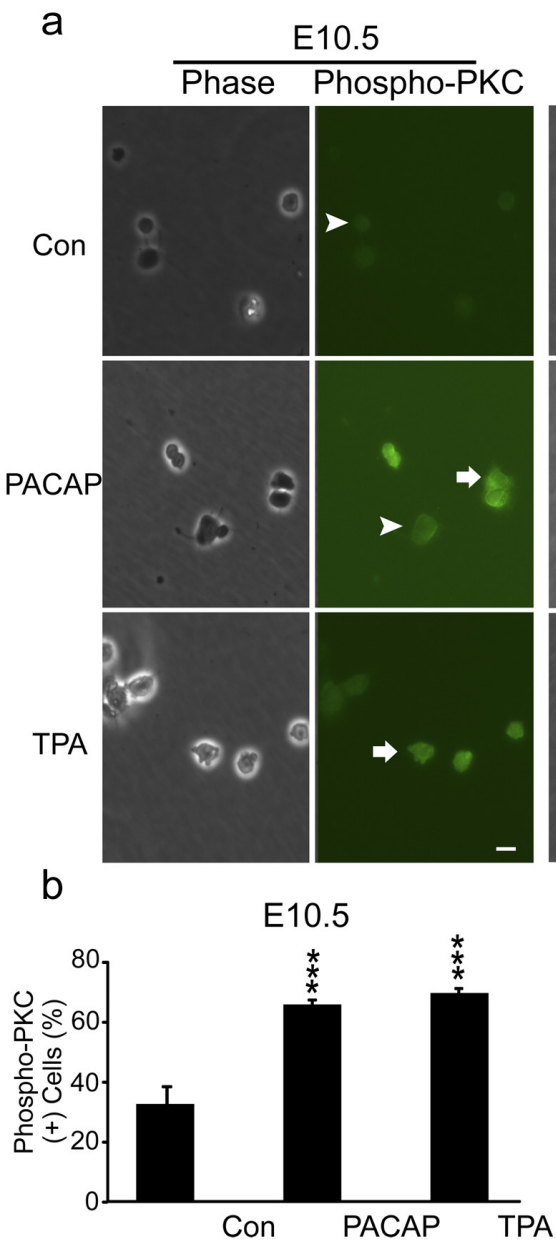
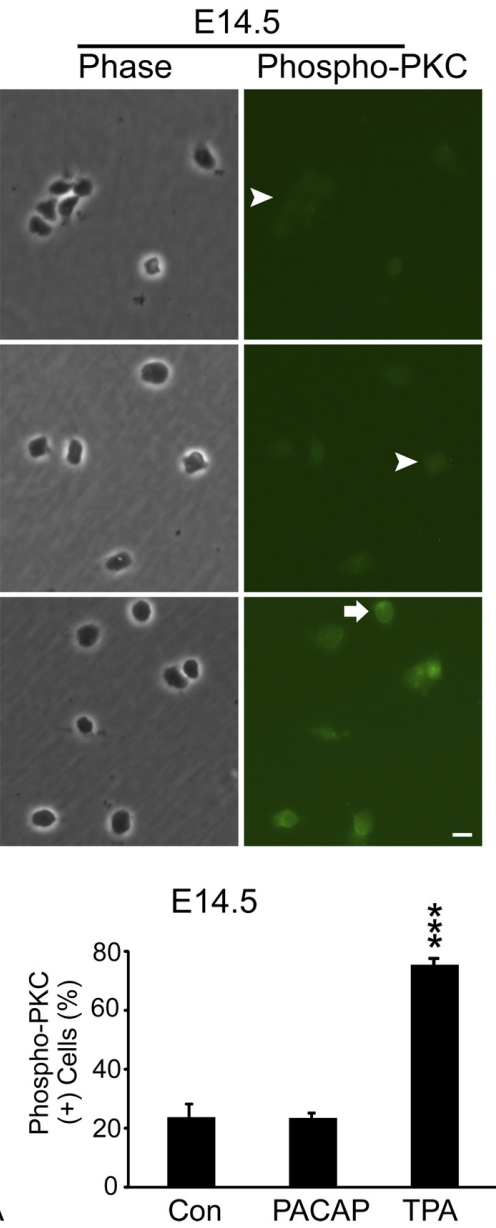

Figure 9. PACAP activates PKC in early E10.5 cortical precursors but not in E14.5 cells. a, Patterns of phospho-PKC staining in E10.5 and E14.5 cortical precursors 30 min after treatment with vehicle (Con), PACAP (10 nm), and PKC agonist TPA (200 nm). PACAP exposure increased phospho-PKC-positive cells by twofold compared with vehicle in $2 \mathrm{~h}$ cultures, comparable with the PKC agonist at E10.5. In contrast, PACAP did not elicit changes in phospho-PKC-positive cells at E14.5, whereas both ages responded to agonist TPA. Positive cells are indicated by arrows and negative cells by arrowheads. $\boldsymbol{b}$, Quantification of phospho-PKC immunostaining Cells were plated in $35 \mathrm{~mm}$ dishes in defined media without growth factors, and reagents were added at $2 \mathrm{~h}$ for $30 \mathrm{~min}$. Data are representative of three experiments, three dishes per group per experiment. ${ }^{* * *} p<0.001$.

were able to respond to $40 \mathrm{~mm} \mathrm{KCl}$ (Fig. $8 c, f, g$ ), suggesting that a depolarization-induced $\mathrm{Ca}^{2+}$ response, specifically influx, was maintained by cells at both stages. We did note that PACAP induced complex $\mathrm{Ca}^{2+}$ oscillation curves, especially compared with those elicited by $\mathrm{KCl}$ (Fig. $8 d, f, g$ ), but did not pursue this further as others have defined mechanisms of $\mathrm{IP}_{3}$ induced $\mathrm{Ca}^{2+}$ oscillations (Berridge et al., 2003; Hogan et al., 2010).

\section{PACAP activates PKC but not MAPK during} early neurogenesis

Another signal downstream of PLC production of DAG and $\mathrm{Ca}^{2+}$ elevation is PKC (Nishizuka, 1984). Initial activation of $\mathrm{PKC}$ can be mediated by its phosphorylation, which may serve as a 
a
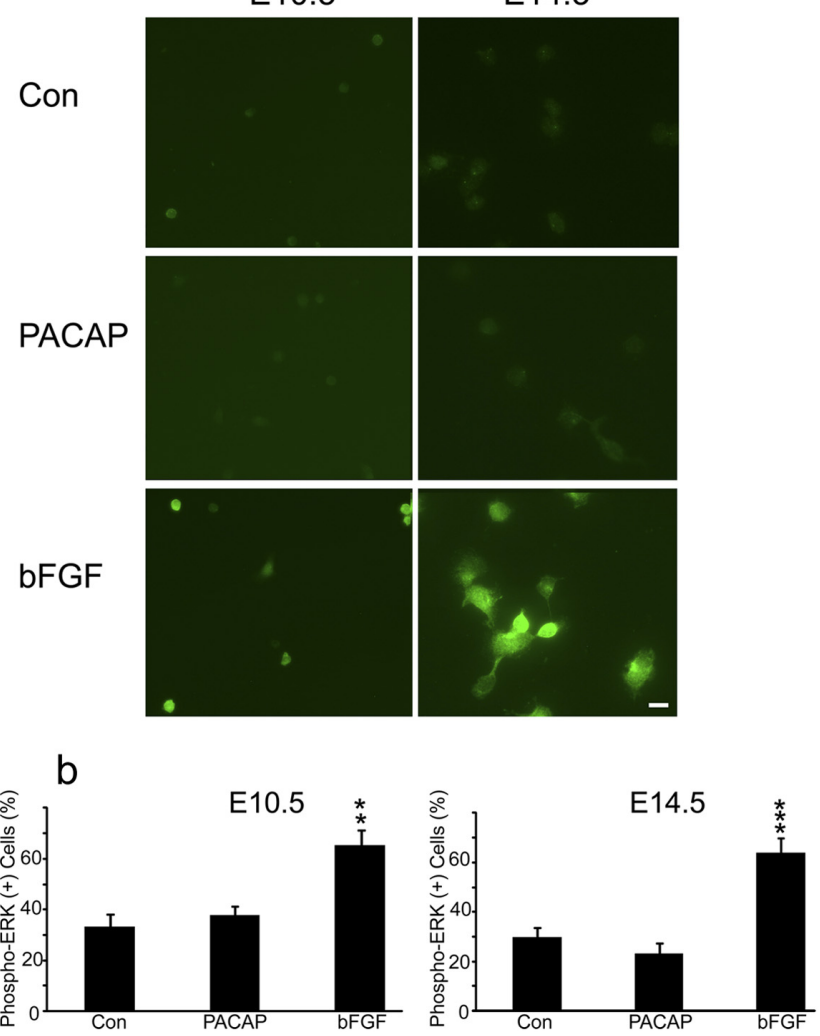

Figure 10. PACAP did not activate phospho-ERK, whereas bFGF exposure led to ERK activation in both E10.5 and E14.5 precursors. $\boldsymbol{a}$, Examples of phospho-ERK staining in E10.5 and E14.5 $10 \mathrm{~min}$ after treatment with vehicle (Con), PACAP (10 nm), and bFGF (10 ng/ml). $\boldsymbol{b}$, Quantification of phospho-ERK immunostaining. Cells were plated in $35 \mathrm{~mm}$ dishes in defined media without growth factors, and reagents were added at $2 \mathrm{~h}$ for $10 \mathrm{~min}$. Data are representative of three experiments, three dishes per group. ${ }^{* *} p<0.01$, $^{* *} p<0.001$. Scale bar, $10 \mu \mathrm{m}$.

molecular marker (Pearce et al., 2010). PACAP treatment (30 min) produced a twofold increase in phospho-PKC immunoreactivity in E10.5 cortical precursors, a response nearly identical to that elicited by the potent PKC agonist 12-O-tetradecanoylphorbol-13-acetate (TPA) (Fig. 9). In contrast, PACAP did not elicit changes in phospho-PKC levels of E14.5 precursors, although a robust threefold response was elicited by TPA (Fig. 9, E14.5). In addition, because PACAP has been shown to activate MAPK pathways in several culture systems (Barrie et al., 1997; Vaudry et al., 2002a), we performed similar studies and assessed phosphorylated ERK. However, PACAP did not elicit increased phospho-ERK in either E10.5 or E14.5 cultures, whereas bFGF, a relevant cortical mitogen (Vaccarino et al., 1999; Li and DiCicco-Bloom, 2004), elicited robust ERK activation in parallel dishes at both ages (Fig. 10), suggesting that PACAP mitogenic signaling is independent of ERK pathways in early precursors, consistent with previous work (Gerdin and Eiden, 2007).

\section{Discussion}

Our observations provide compelling evidence that PACAP contributes to neuronal precursor proliferation through agedependent bidirectional activity during cortical development. PACAP exhibits pro-mitogenic effects during early neurogenesis, whereas the peptide may restrain proliferation from E12.5 onward. The temporally specific effects on proliferation are mediated by developmental expression of PAC1 receptor isoforms, with hop predominating early followed by short expression later. PACAP signaling provides a novel example in the developing nervous system that alternative splicing of receptor mRNA isoforms differentially controls cortical proliferation.

During early neurogenesis, when stem cells are proliferating to enlarge precursor pools, PACAP enhances proliferation through the hop isoform: it increases DNA synthesis and promotes $G_{1} / S$ progression and cell division without affecting survival. The stimulation elicited by PACAP in vitro is consistent with reduced mitotic labeling in the $\mathrm{KO}$ in vivo, in which the $13 \%$ reduction is comparable with the $14 \%$ decrease observed in the bFGF/FGF2 null (Vaccarino et al., 1999). However, several extracellular factors (FGF2, Wnts, Shh, BMPs) that regulate proliferation and neurogenesis coexist in developing cortex (Stevens et al., 2010) and may partially compensate one another. Although PACAP may elicit modest effects as a result of a selectively responsive cell subset, PAC1 expression appears to be nearly universal (Basille et al., 2000; Suh et al., 2001; Nishimoto et al., 2007), although PAC1 isoform-selective reagents have not yet been developed.

During early neurogenesis when hop predominates, PACAP activates PLC and calcium fluxes, enhancing PKC phosphorylation and $G_{1}$-stage $D$ cyclins. Significantly, the important role for the PAC1 hop isoform in early precursors is indicated by the blockade of PACAP mtiogenic stimulation in the presence of hop shRNAs. To our knowledge, this is the first use of knockdown techniques to define activities of hop isoform and for defining roles of third intracellular loops of GPCRs. Conversely, maintaining elevated hop/short ratios through RA treatment sustained pro-mitogenic activity beyond this early developmental window. However, with increasing age and short expression, PACAP promotes cell cycle exit. PACAP induces cell cycle exit by selective increases in cyclin-dependent kinase inhibitor p57 ${ }^{\text {kip2 }}$ (not p $27^{\text {kip1 }}$ ) activity and association with CDK2/cyclin E complex (Carey et al., 2002; Tury et al., 2011).

One caveat of these studies is use of WT cells, which release PACAP as an autocrine regulator of proliferation ( $\mathrm{Lu}$ and DiCicco-Bloom, 1997; Suh et al., 2001). We attempted to compare roles of exogenous and endogenous PACAP by dissecting littermates from heterozygote crosses, but too few E9.5 cells were available for single cortex analysis. However, we assessed E14.5 WT and PACAP KO precursors and found that PACAP elicited $\sim 35 \%$ reductions in DNA synthesis (WT: control, $100 \pm 9 \%$ and PACAP, $62 \pm 6 \%$; KO: control, $100 \pm 7 \%$ and PACAP, $67 \pm 8 \%$; $n=6$ wells, 2 experiments), consistent with previous antimitogenic effects (Lu and DiCicco-Bloom, 1997; Lu et al., 1998; Suh et al., 2001; Carey et al., 2002). Significantly, there was no difference in survival of PACAP KO precursors compared with WT littermates, suggesting that trophic mechanisms were not involved at E14.5, as we observed at E10.5 (Figs. 1,4). Thus, in the absence of peptide, PACAP response systems appear to function normally, as suggested by previous expression analyses (Girard et al., 2006).

Current neural precursor/stem cell cultures include adherent cells, neurospheres, mixed cell cocultures, and serum-free suspension cultures (Qian et al., 1998; Shen et al., 2004, 2006; Watanabe et al., 2005). These systems may be technically demanding, requiring cell shaking and centrifugation (Qian et al., 1998), preplating with endothelial cells (Shen et al., 2004), or incubation with soluble factors (Watanabe et al., 2005). Procedures for our culture system are relatively less complicated. Furthermore, the precursors are ready for immediate use, an attribute that may preserve comparability with their in vivo state and may mitigate against emergence of traits reflecting adaptation to culture. The defined culture medium contains a restricted 
panel of factors (insulin, bFGF, and BDNF). Although this simplified medium may not support certain developmental events, we were able to test effects of steroids and RA, as well as use shRNA knockdown techniques. One possible limitation is use of trypsin to separate overlying epidermis from brain, because this may alter surface receptors or ion channels. There may be variability in dissecting cortex away from the medial (future hippocampus) and ventral (future ganglionic eminences) telencephalic vesicles, because specific boundary markers are unavailable. Nonetheless, the consistent stimulatory effect of PACAP at E10.5 and its opposite activity at E14.5 suggests the temporal transition in PAC1 isoforms may control forebrain development. Future studies should define the precise localization of $\mathrm{PACl}$ isoform expression in combination with lineage-specific markers for cortex, hippocampus, and basal ganglia.

Our observations suggest that precursors in vitro undergo the developmental transition in response to PACAP observed in vivo. Although E10.5 cells exhibited mitotic stimulation in response to PACAP, if first cultured for $24 \mathrm{~h}, \mathrm{PACAP}$ then elicited no increase in DNA synthesis, a response that is identical to that of cells obtained directly from E11.5 embryos, although additional studies may be required. The fact that RA induced PAC1 hop isoform expression and maintained PACAP mitogenic activity indicates that these cells are plastic and responsive to environmental cues. We chose RA because previous studies indicate that it regulates PACAP receptors (Waschek et al., 1997). RA can promote the transition from radial glial symmetric division to asymmetric production of intermediate cortical precursors and neurons (Siegenthaler et al., 2009). Thus, it is possible that RA induces changes in the proportions of cortical precursors that may influence PACAP effects, an interesting direction for additional studies. Regardless, our culture system provides a different platform in which to elucidate intrinsic and extrinsic regulation of neural stem cells and may provide insights into stem cell division patterns, potency, and windows of plasticity.

Understanding regulation of PACAP pro-mitogenic activity could provide a strategy for stem-cell-based regenerative therapy because PACAP stimulates neural stem cell proliferation and promotes neurogenesis in vitro and in vivo (Mercer et al., 2004; Ohta et al., 2006; Scharf et al., 2008; Fang et al., 2010), although it can also modulate gliogenesis (including oligodendrocytes and astrocytes) under different conditions (Lee et al., 2001; Nishimoto et al., 2007). It remains uncertain whether short (Ohta et al., 2006; Scharf et al., 2008) or hop (Mercer et al., 2004) isoforms mediated proliferative stimulation because both forms were detected and both cAMP and PLC/PKC pathways were activated in adult subventricular zone and dentate gyrus, suggesting that both regional and temporal specificity is involved. Our study demonstrates that PACAP pro-mitogenic activity is mediated through the hop isoform and that developmental upregulation of the short isoform may restrain precursor proliferation in developing cortex. Furthermore, although cAMP and ERK activation are both downstream of PACAP in some systems (Gerdin and Eiden, 2007), our studies suggest that hop isoform stimulates early cortical precursor proliferation through PLC/PKC pathways and $G_{1}$ cyclins, although we cannot exclude involvement of other signaling mechanisms. In addition, although continued expression of hop mRNA (and presumably protein) in E14.5 precursors would predict a phospho-PKC response to PACAP treatment at this age, its absence raises several questions regarding the coupling of PAC1 hop to G-proteins, age-dependent expression of G-protein family members, downstream signaling, or inhibitory crosstalk between short and hop isoforms that warrant future study.

The model of a developmental transition in PAC1 splice isoform expression provides an important target for future exploration of mRNA splicing mechanisms. Developmental control of neurogenesis through RNA splicing of receptors that regulate proliferation is not commonly reported in the nervous system. However, alternative isoforms of cytosolic adaptor protein NUMB regulate proliferation and differentiation in P19 carcinoma cells (Verdi et al., 1999) and cortical precursors (BaniYaghoub et al., 2007). Similarly in cancer cells, the predominant fibroblast growth factor receptor 3 (FGFR3) elicits stimulation, whereas a normal FGFR3 splice variant $(\Delta 8-10)$ inhibits proliferation. The regulation of proliferation depended on the ratio of different splice isoforms, with loss of the inhibitory variant leading to uncontrolled proliferation (Tomlinson et al., 2005). In adult cerebral cortex, antagonistic effects of dopamine in the synapse also depend on the ratio of dopamine $\mathrm{D}_{2}$ receptor isoforms, $\mathrm{D}_{2} \mathrm{~L}$ and $\mathrm{D}_{2} \mathrm{R}$ (Picetti et al., 1997), which are generated by alternative splicing of a 29 aa insert in the third intracellular loop (Usiello et al., 2000), similar to PAC1. Control of pre-mRNA splicing is a complex process that involves many layers of regulation (Li et al., 2007; Greenberg et al., 2009). Recent research indicates that alternative splicing is frequent during embryonic development (E8.5-E11.5 in mouse) including the PACAP system, and alternative splicing is disproportionately involved in neurogenesis (Revil et al., 2010). Thus, defining splicing regulation may provide insights into neuropsychiatric disorders, such as schizophrenia, PTSD, and autism (Hashimoto et al., 2007; Nijmeijer et al., 2010; Ressler et al., 2011).

In conclusion, PACAP signaling influences precursor mitosis during brain development. The developmental switch in PAC1 hop and short isoforms converts PACAP mitogenic stimulation to inhibition. It is likely that the PAC1 receptor is but one of many signals governing corticogenesis that is subject to regulation by mechanisms controlling mRNA splicing.

\section{References}

Arimura A (1992) Pituitary adenylate cyclase activating polypeptide (PACAP): discovery and current status of research. Regul Pept 37:287303. Medline

Bani-Yaghoub M, Kubu CJ, Cowling R, Rochira J, Nikopoulos GN, Bellum S, Verdi JM (2007) A switch in numb isoforms is a critical step in cortical development. Dev Dyn 236:696-705. CrossRef Medline

Barrie AP, Clohessy AM, Buensuceso CS, Rogers MV, Allen JM (1997) Pituitary adenylyl cyclase-activating peptide stimulates extracellular signalregulated kinase 1 or 2 (ERK1/2) activity in a Ras-independent, mitogenactivated protein kinase/ERK kinase 1 or 2-dependent manner in PC12 cells. J Biol Chem 272:19666-19671. CrossRef Medline

Basille M, Vaudry D, Coulouarn Y, Jegou S, Lihrmann I, Fournier A, Vaudry H, Gonzalez B (2000) Comparative distribution of pituitary adenylate cyclase-activating polypeptide (PACAP) binding sites and PACAP receptor mRNAs in the rat brain during development. J Comp Neurol 425:495509. CrossRef Medline

Berridge MJ, Lipp P, Bootman MD (2000) The versatility and universality of calcium signalling. Nat Rev Mol Cell Biol 1:11-21. CrossRef Medline

Berridge MJ, Bootman MD, Roderick HL (2003) Calcium signalling: dynamics, homeostasis and remodelling. Nat Rev Mol Cell Biol 4:517-529. CrossRef Medline

Carey RG, Li B, DiCicco-Bloom E (2002) Pituitary adenylate cyclase activating polypeptide anti-mitogenic signaling in cerebral cortical progenitors is regulated by p57Kip2-dependent CDK2 activity. J Neurosci 22:15831591. Medline

Colwell CS, Michel S, Itri J, Rodriguez W, Tam J, Lelièvre V, Hu Z, Waschek JA (2004) Selective deficits in the circadian light response in mice lacking PACAP. Am J Physiol Regul Integr Comp Physiol 287:R1194-R1201. CrossRef Medline 
Culican SM, Baumrind NL, Yamamoto M, Pearlman AL (1990) Cortical radial glia: identification in tissue culture and evidence for their transformation to astrocytes. J Neurosci 10:684-692. Medline

DiCicco-Bloom E, Deutsch PJ, Maltzman J, Zhang J, Pintar JE, Zheng J, Friedman WF, Zhou X, Zaremba T (2000) Autocrine expression and ontogenetic functions of the PACAP ligand/receptor system during sympathetic development. Dev Biol 219:197-213. CrossRef Medline

Fang KM, Chen JK, Hung SC, Chen MC, Wu YT, Wu TJ, Lin HI, Chen CH, Cheng H, Yang CS, Tzeng SF (2010) Effects of combinatorial treatment with pituitary adenylate cyclase activating peptide and human mesenchymal stem cells on spinal cord tissue repair. PLoS One 5:e15299. CrossRef Medline

Francone VP, Ifrim MF, Rajagopal C, Leddy CJ, Wang Y, Carson JH, Mains RE, Eipper BA (2010) Signaling from the secretory granule to the nucleus: Uhmk1 and PAM. Mol Endocrinol 24:1543-1558. CrossRef Medline

Gerdin MJ, Eiden LE (2007) Regulation of PC12 cell differentiation by cAMP signaling to ERK independent of PKA: do all the connections add up? Sci STKE 2007:pe15. CrossRef Medline

Girard BA, Lelievre V, Braas KM, Razinia T, Vizzard MA, Ioffe Y, El Meskini R, Ronnett GV, Waschek JA, May V (2006) Noncompensation in peptide/receptor gene expression and distinct behavioral phenotypes in VIPand PACAP-deficient mice. J Neurochem 99:499-513. CrossRef Medline

Greenberg ME, Xu B, Lu B, Hempstead BL (2009) New insights in the biology of BDNF synthesis and release: implications in CNS function. J Neurosci 29:12764-12767. CrossRef Medline

Harmar AJ, Arimura A, Gozes I, Journot L, Laburthe M, Pisegna JR, Rawlings SR, Robberecht P, Said SI, Sreedharan SP, Wank SA, Waschek JA (1998) International Union of Pharmacology. XVIII. Nomenclature of receptors for vasoactive intestinal peptide and pituitary adenylate cyclase-activating polypeptide. Pharmacol Rev 50:265-270. Medline

Hashimoto R, Hashimoto H, Shintani N, Chiba S, Hattori S, Okada T, Nakajima M, Tanaka K, Kawagishi N, Nemoto K, Mori T, Ohnishi T, Noguchi H, Hori H, Suzuki T, Iwata N, Ozaki N, Nakabayashi T, Saitoh O, Kosuga A, Tatsumi M, Kamijima K, Weinberger DR, Kunugi H, Baba A (2007) Pituitary adenylate cyclase-activating polypeptide is associated with schizophrenia. Mol Psychiatry 12:1026-1032. CrossRef Medline

Haskell GT, LaMantia AS (2005) Retinoic acid signaling identifies a distinct precursor population in the developing and adult forebrain. J Neurosci 25:7636-7647. CrossRef Medline

Hegg CC, Au E, Roskams AJ, Lucero MT (2003) PACAP is present in the olfactory system and evokes calcium transients in olfactory receptor neurons. J Neurophysiol 90:2711-2719. CrossRef Medline

Hogan PG, Lewis RS, Rao A (2010) Molecular basis of calcium signaling in lymphocytes: STIM and ORAI. Annu Rev Immunol 28:491-533. CrossRef Medline

Lee M, Lelievre V, Zhao P, Torres M, Rodriguez W, Byun JY, Doshi S, Ioffe Y, Gupta G, de los Monteros AE, de Vellis J, Waschek J (2001) Pituitary adenylyl cyclase-activating polypeptide stimulates DNA synthesis but delays maturation of oligodendrocyte progenitors. J Neurosci 21:38493859. Medline

Lewis RS (2003) Calcium oscillations in T-cells: mechanisms and consequences for gene expression. Biochem Soc Trans 31:925-929. CrossRef Medline

Li B, DiCicco-Bloom E (2004) Basic fibroblast growth factor exhibits dual and rapid regulation of cyclin D1 and p27 to stimulate proliferation of rat cerebral cortical precursors. Dev Neurosci 26:197-207. CrossRef Medline

Li Q, Lee JA, Black DL (2007) Neuronal regulation of alternative pre-mRNA splicing. Nat Rev Neurosci 8:819-831. CrossRef Medline

Lu N, DiCicco-Bloom E (1997) Pituitary adenylate cyclase-activating polypeptide is an autocrine inhibitor of mitosis in cultured cortical precursor cells. Proc Natl Acad Sci U S A 94:3357-3362. CrossRef Medline

Lu N, Zhou R, DiCicco-Bloom E (1998) Opposing mitogenic regulation by PACAP in sympathetic and cerebral cortical precursors correlates with differential expression of PACAP receptor (PAC1-R) isoforms. J Neurosci Res 53:651-662. CrossRef Medline

Mairet-Coello G, Tury A, DiCicco-Bloom E (2009) Insulin-like growth factor-1 promotes $\mathrm{G}(1) / \mathrm{S}$ cell cycle progression through bidirectional regulation of cyclins and cyclin-dependent kinase inhibitors via the phosphatidylinositol 3-kinase/Akt pathway in developing rat cerebral cortex. J Neurosci 29:775-788. CrossRef Medline

Malagelada C, López-Toledano MA, Willett RT, Jin ZH, Shelanski ML,
Greene LA (2011) RTP801/REDD1 regulates the timing of cortical neurogenesis and neuron migration. J Neurosci 31:3186-3196. CrossRef Medline

Malatesta P, Hack MA, Hartfuss E, Kettenmann H, Klinkert W, Kirchhoff F, Götz M (2003) Neuronal or glial progeny: regional differences in radial glia fate. Neuron 37:751-764. CrossRef Medline

Ménard C, Hein P, Paquin A, Savelson A, Yang XM, Lederfein D, BarnabéHeider F, Mir AA, Sterneck E, Peterson AC, Johnson PF, Vinson C, Miller FD (2002) An essential role for a MEK-C/EBP pathway during growth factor-regulated cortical neurogenesis. Neuron 36:597-610. CrossRef Medline

Mercer A, Rönnholm H, Holmberg J, Lundh H, Heidrich J, Zachrisson O, Ossoinak A, Frisén J, Patrone C (2004) PACAP promotes neural stem cell proliferation in adult mouse brain. J Neurosci Res 76:205-215. CrossRef Medline

Nicot A, DiCicco-Bloom E (2001) Regulation of neuroblast mitosis is determined by PACAP receptor isoform expression. Proc Natl Acad Sci U S A 98:4758-4763. CrossRef Medline

Nicot A, Lelièvre V, Tam J, Waschek JA, DiCicco-Bloom E (2002) Pituitary adenylate cyclase-activating polypeptide and sonic hedgehog interact to control cerebellar granule precursor cell proliferation. J Neurosci 22: 9244-9254. Medline

Nijmeijer JS, Arias-Vásquez A, Rommelse NN, Altink ME, Anney RJ, Asherson P, Banaschewski T, Buschgens CJ, Fliers EA, Gill M, Minderaa RB, Poustka L, Sergeant JA, Buitelaar JK, Franke B, Ebstein RP, Miranda A, Mulas F, Oades RD, Roeyers H, Rothenberger A, Sonuga-Barke EJ, Steinhausen HC, Faraone SV, Hartman CA, Hoekstra PJ (2010) Identifying loci for the overlap between attention-deficit/hyperactivity disorder and autism spectrum disorder using a genome-wide QTL linkage approach. J Am Acad Child Adolesc Psychiatry 49:675-685. CrossRef Medline

Nishimoto M, Furuta A, Aoki S, Kudo Y, Miyakawa H, Wada K (2007) $\mathrm{PACAP} / \mathrm{PACl}$ autocrine system promotes proliferation and astrogenesis in neural progenitor cells. Glia 55:317-327. CrossRef Medline

Nishizuka Y (1984) The role of protein kinase C in cell surface signal transduction and tumour promotion. Nature 308:693-698. CrossRef Medline

Noctor SC, Martínez-Cerdeño V, Ivic L, Kriegstein AR (2004) Cortical neurons arise in symmetric and asymmetric division zones and migrate through specific phases. Nat Neurosci 7:136-144. CrossRef Medline

Ohta S, Gregg C, Weiss S (2006) Pituitary adenylate cyclase-activating polypeptide regulates forebrain neural stem cells and neurogenesis in vitro and in vivo. J Neurosci Res 84:1177-1186. CrossRef Medline

Pan Z, Damron D, Nieminen AL, Bhat MB, Ma J (2000) Depletion of intracellular $\mathrm{Ca}^{2+}$ by caffeine and ryanodine induces apoptosis of chinese hamster ovary cells transfected with ryanodine receptor. J Biol Chem 275:19978-19984. CrossRef Medline

Pearce LR, Komander D, Alessi DR (2010) The nuts and bolts of AGC protein kinases. Nat Rev Mol Cell Biol 11:9-22. CrossRef Medline

Picetti R, Saiardi A, Abdel Samad T, Bozzi Y, Baik JH, Borrelli E (1997) Dopamine D2 receptors in signal transduction and behavior. Crit Rev Neurobiol 11:121-142. CrossRef Medline

Qian X, Goderie SK, Shen Q, Stern JH, Temple S (1998) Intrinsic programs of patterned cell lineages in isolated vertebrate CNS ventricular zone cells. Development 125:3143-3152. Medline

Ressler KJ, Mercer KB, Bradley B, Jovanovic T, Mahan A, Kerley K, Norrholm SD, Kilaru V, Smith AK, Myers AJ, Ramirez M, Engel A, Hammack SE, Toufexis D, Braas KM, Binder EB, May V (2011) Post-traumatic stress disorder is associated with PACAP and the PAC1 receptor. Nature 470: 492-497. CrossRef Medline

Revil T, Gaffney D, Dias C, Majewski J, Jerome-Majewska LA (2010) Alternative splicing is frequent during early embryonic development in mouse. BMC Genomics 11:399. CrossRef Medline

Romito-DiGiacomo RR, Menegay H, Cicero SA, Herrup K (2007) Effects of Alzheimer's disease on different cortical layers: the role of intrinsic differences in Abeta susceptibility. J Neurosci 27:8496-8504. CrossRef Medline

Schaar BT, Kinoshita K, McConnell SK (2004) Doublecortin microtubule affinity is regulated by a balance of kinase and phosphatase activity at the leading edge of migrating neurons. Neuron 41:203-213. CrossRef Medline

Scharf E, May V, Braas KM, Shutz KC, Mao-Draayer Y (2008) Pituitary adenylate cyclase-activating polypeptide (PACAP) and vasoactive intestinal peptide (VIP) regulate murine neural progenitor cell survival, proliferation, and differentiation. J Mol Neurosci 36:79-88. CrossRef Medline 
Shen Q, Goderie SK, Jin L, Karanth N, Sun Y, Abramova N, Vincent P, Pumiglia K, Temple S (2004) Endothelial cells stimulate self-renewal and expand neurogenesis of neural stem cells. Science 304:1338-1340. CrossRef Medline

Shen Q, Wang Y, Dimos JT, Fasano CA, Phoenix TN, Lemischka IR, Ivanova NB, Stifani S, Morrisey EE, Temple S (2006) The timing of cortical neurogenesis is encoded within lineages of individual progenitor cells. Nat Neurosci 9:743-751. CrossRef Medline

Siegenthaler JA, Ashique AM, Zarbalis K, Patterson KP, Hecht JH, Kane MA, Folias AE, Choe Y, May SR, Kume T, Napoli JL, Peterson AS, Pleasure SJ (2009) Retinoic acid from the meninges regulates cortical neuron generation. Cell 139:597-609. CrossRef Medline

Spengler D, Waeber C, Pantaloni C, Holsboer F, Bockaert J, Seeburg PH, Journot L (1993) Differential signal transduction by five splice variants of the PACAP receptor. Nature 365:170-175. CrossRef Medline

Stevens HE, Smith KM, Rash BG, Vaccarino FM (2010) Neural stem cell regulation, fibroblast growth factors, and the developmental origins of neuropsychiatric disorders. Front Neurosci 4:59. CrossRef Medline

Studer M, Pöpperl H, Marshall H, Kuroiwa A, Krumlauf R (1994) Role of a conserved retinoic acid response element in rhombomere restriction of Hoxb-1. Science 265:1728-1732. CrossRef Medline

Suh J, Lu N, Nicot A, Tatsuno I, DiCicco-Bloom E (2001) PACAP is an anti-mitogenic signal in developing cerebral cortex. Nat Neurosci 4:123124. CrossRef Medline

Tomlinson DC, L'Hôte CG, Kennedy W, Pitt E, Knowles MA (2005) Alternative splicing of fibroblast growth factor receptor 3 produces a secreted isoform that inhibits fibroblast growth factor-induced proliferation and is repressed in urothelial carcinoma cell lines. Cancer Res 65:10441-10449. CrossRef Medline

Tury A, Mairet-Coello G, DiCicco-Bloom E (2011) The cyclindependent kinase inhibitor p57Kip2 regulates cell cycle exit, differentiation, and migration of embryonic cerebral cortical precursors. Cereb Cortex 21:1840-1856. CrossRef Medline

Usiello A, Baik JH, Rougé-Pont F, Picetti R, Dierich A, LeMeur M, Piazza PV, Borrelli E (2000) Distinct functions of the two isoforms of dopamine D2 receptors. Nature 408:199-203. CrossRef Medline

Vaccarino FM, Schwartz ML, Raballo R, Nilsen J, Rhee J, Zhou M, Doetschman T, Coffin JD, Wyland JJ, Hung YT (1999) Changes in cerebral cortex size are governed by fibroblast growth factor during embryogenesis. Nat Neurosci 2:246-253. CrossRef Medline

Vaudry D, Stork PJ, Lazarovici P, Eiden LE (2002a) Signaling pathways for PC12 cell differentiation: making the right connections. Science 296:1648-1649. CrossRef Medline

Vaudry D, Chen Y, Ravni A, Hamelink C, Elkahloun AG, Eiden LE (2002b) Analysis of the PC12 cell transcriptome after differentiation with pituitary adenylate cyclase-activating polypeptide (PACAP). J Neurochem 83: 1272-1284. CrossRef Medline

Vaudry D, Rousselle C, Basille M, Falluel-Morel A, Pamantung TF, Fontaine M, Fournier A, Vaudry H, Gonzalez BJ (2002c) Pituitary adenylate cyclase-activating polypeptide protects rat cerebellar granule neurons against ethanol-induced apoptotic cell death. Proc Natl Acad Sci U S A 99:6398-6403. CrossRef Medline

Vaudry D, Falluel-Morel A, Bourgault S, Basille M, Burel D, Wurtz O, Fournier A, Chow BK, Hashimoto H, Galas L, Vaudry H (2009) Pituitary adenylate cyclase-activating polypeptide and its receptors: 20 years after the discovery. Pharmacol Rev 61:283-357. CrossRef Medline

Verdi JM, Bashirullah A, Goldhawk DE, Kubu CJ, Jamali M, Meakin SO, Lipshitz HD (1999) Distinct human NUMB isoforms regulate differentiation vs. proliferation in the neuronal lineage. Proc Natl Acad Sci U S A 96:10472-10476. CrossRef Medline

Waschek JA (2002) Multiple actions of pituitary adenylyl cyclase activating peptide in nervous system development and regeneration. Dev Neurosci 24:14-23. CrossRef Medline

Waschek JA, Lelievre V, Bravo DT, Nguyen T, Muller JM (1997) Retinoic acid regulation of the VIP and PACAP autocrine ligand and receptor system in human neuroblastoma cell lines. Peptides 18:835-841. CrossRef Medline

Waschek JA, Casillas RA, Nguyen TB, DiCicco-Bloom EM, Carpenter EM, Rodriguez WI (1998) Neural tube expression of pituitary adenylate cyclase-activating peptide (PACAP) and receptor: potential role in patterning and neurogenesis. Proc Natl Acad Sci U S A 95:9602-9607. CrossRef Medline

Watanabe K, Kamiya D, Nishiyama A, Katayama T, Nozaki S, Kawasaki H, Watanabe Y, Mizuseki K, Sasai Y (2005) Directed differentiation of telencephalic precursors from embryonic stem cells. Nat Neurosci 8:288-296. CrossRef Medline

Weissman TA, Riquelme PA, Ivic L, Flint AC, Kriegstein AR (2004) Calcium waves propagate through radial glial cells and modulate proliferation in the developing neocortex. Neuron 43:647-661. CrossRef Medline

Zhou C, Kikuyama S, Nakajo S, Hirabayashi T, Mizushima H, Shioda S (2000) Splice variants of PAC(1) receptor during early neural development of rats. Peptides 21:1177-1183. CrossRef Medline 